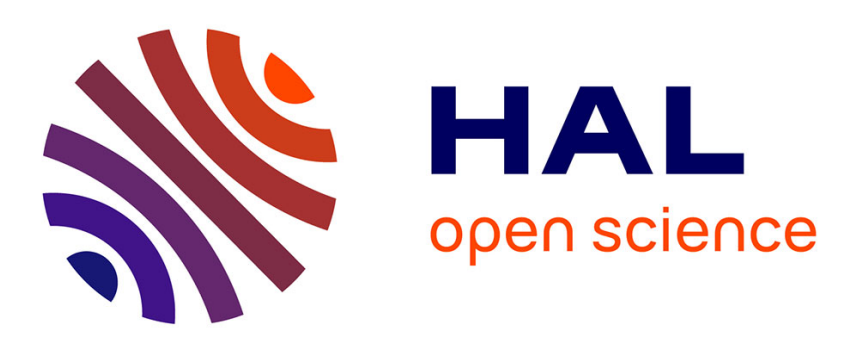

\title{
Effect of groundwater and sea weathering cycles on the strength of chalk rock from unstable coastal cliffs of NW France
}

Anne Duperret, Said Taibi, Rory N. Mortimore, Martin Daigneault

\section{To cite this version:}

Anne Duperret, Said Taibi, Rory N. Mortimore, Martin Daigneault. Effect of groundwater and sea weathering cycles on the strength of chalk rock from unstable coastal cliffs of NW France. Engineering Geology, 2005, 78, pp.321-343. 10.1016/j.enggeo.2005.01.004 . insu-00799866

\section{HAL Id: insu-00799866 \\ https://hal-insu.archives-ouvertes.fr/insu-00799866}

Submitted on 12 Mar 2013

HAL is a multi-disciplinary open access archive for the deposit and dissemination of scientific research documents, whether they are published or not. The documents may come from teaching and research institutions in France or abroad, or from public or private research centers.
L'archive ouverte pluridisciplinaire HAL, est destinée au dépôt et à la diffusion de documents scientifiques de niveau recherche, publiés ou non, émanant des établissements d'enseignement et de recherche français ou étrangers, des laboratoires publics ou privés. 


\title{
Effect of groundwater and sea weathering cycles on the strength of chalk rock from unstable coastal cliffs of NW France.
}

\author{
Anne Duperret ${ }^{1^{*}}$, Said Taibi ${ }^{1}$, Rory N. Mortimore ${ }^{2}$, Martin Daigneault ${ }^{1}$
}

1. Laboratoire de Mécanique, Physique et Géosciences, Université du Havre, 25 rue Philippe Lebon, BP540, 76058 Le Havre cedex, France

2. Applied Geology Research Unit, School of the Environment, University of Brighton, Moulsecoomb, Brighton, BN24GJ, United Kingdom.

\begin{abstract}
The aim of this paper is to evaluate the role of ground water and sea weathering on the strength of the chalk rocks exposed on the coastline of the English Channel in Normandy, NW France. We present a study of the rock strength variations of three representative chalk units (Lewes Chalk, Seaford Chalk and Newhaven Chalk) exposed at various locations on the coastal chalk cliffs. The combination of UCS tests and SEM observations have been used (1) on dry natural chalk samples, (2) on chalk samples at various moisture contents, (3) on dry chalk samples submitted to a 10 day cycle of alternating wetting and drying by distilled water and by sea water. Dry chalk samples show low UCS strength $(3.46-4 \mathrm{MPa})$ indicative of very weak rocks. When chalk samples are submitted to progressive water wetting, they present a decrease of UCS strength and Young's modulus of $40 \%$ to $50 \%$. This behaviour begins at low values of water content within the chalk, i.e. for a degree of water saturation ranging between $10 \%$ and $17 \%$. When chalk samples are submitted to an artificial weathering cycle with distilled water, a decrease in strength varying from $20 \%$ to $47 \%$ is observed. SEM observations indicate the occurrence of microcracks and particle aggregates in the sample. When chalk samples are submitted to an artificial weathering with sea water, the decrease of UCS strength and Young's modulus achieves a maximum with $52 \%$ to $73 \%$ respectively. SEM observations indicate salt crystals within the chalk. On the coastal cliffs of NW France, weathering processes is depend both on chalk lithology, which show a range of sensitivity to weathering and on the location of
\end{abstract}

"corresponding author : anne.duperret@univ-lehavre.fr, Fax : +(33) 232744960 
the chalk in the coastal area. Processes allied to the degree of weathering (e.g. salt crystallisation or fresh water disaggregation) differ in the chalk massif, on the cliff face and on the shore platform.

\section{Introduction}

Chalk cliffs of Upper-Normandy are located on the French side of the English Channel and suffer high rates of coastal erosion. Mean long-term chalk cliff erosion rates for the English Channel are about $0.25 \mathrm{~m} /$ year (Costa, 2000 ; Dornbusch et al., 2001). As observed over short periods of a few years chalk cliff erosion occurs by sudden collapses in Upper-Normandy and Picardy (Duperret et al., 2002, 2004) and in Nord region (Lahousse and Pierre, 2003).

The evolution of a coastal cliff from stability toward failure, depends on changes in the rock mass (lithology, fracture pattern), and processes acting within the rock mass (degree of water saturation, water movement) caused by external agencies of subaerial and marine origin. External agencies lead to the development and opening of fractures (resulting from stress relief, fatigue, wetting and drying, freeze-thaw action) and the deterioration of the rock material as a result of the infiltration of water (resulting in solution, chemical alteration, physical breakdown through freeze-thaw or salt crystallisation).

During the European research project ROCC (Risk Of Cliff Collapse), a large number of studies were conducted on the geological framework of the coastline (chalk lithology and fracture mapping) and on the determination of the external agencies of subaerial and marine origin which contribute to the instability of coastal chalk cliffs (e.g. Brossard and Duperret, 2004 ; Duperret et al., 2004 ; Genter et al., 2004 ; Mortimore et al., 2004). The next stage is to quantify the effect of external agencies on the chalk properties and to determine the relative contribution of various processes of weathering on chalk, in order to model the mechanical behaviour of the cliff during slope instability evolution.

This paper evaluates the role of ground water and sea weathering on the UCS strength and Young's modulus of chalk exposed in coastal cliffs. Strength variations of three representative chalk units are determined from short cycles of ground-water and sea-water weathering by artificial wetting/drying experiments conducted in laboratory. Experimental studies have helped define the processes of chalk weathering in the coastal environment as a function of their location on the coastline. Several methods 
of moisture imposition in the chalk have been used. The first by conventional soaking in distilled water or sea water and the others by tensiometric plates, osmotic pressure and finally by controlling the relative humidity with salt solutions in dessicators. These different methods were used to try and control the precise moisture content in the samples to compare with UCS tests results.

\section{Geologic background}

\subsection{Coastal chalk cliffs geomorphology}

Coastal chalk cliff exposures along each part of the English Channel are composed of nearly vertical cliffs ranging from 20 to $100 \mathrm{~m}$ high and a chalk shore platform (wave-cut platform, Fairbridge, 1968) with a low angle of slope, often covered with sand and/or shingle. The shore platform is made of eroded chalk or hardgrounds and is subjected to a semi-diurnal cycle of macrotides. The chalk rocks located at the base of the cliffs may be cyclically submitted to weathering by sea-water during high tides and by fresh groundwater that infiltrate within the chalk from rainfall. Weathering of rocks on exposures is generally either chemical and/or mechanical and both contribute to a reduction in the strength of rocks (Sunamura, 1992).

\subsection{Chalk lithostratigraphy on coastal cliffs of NW France}

On the French coast from Le Tilleul to Ault (120 km long), a lithostratigraphic map was constructed (Mortimore, 2001 ; Duperret et al., 2004), using the lithostratigraphic scheme devised in Southern England (Mortimore, 1983, 1986). The synthetic section of chalk unit distribution exposed on the French cliffs indicates the different chalk succession present on a vertical cliff section (Fig. 1). Six Chalk formations are recognized : la craie de Rouen, the Holywell Nodular Chalk, the New Pit Chalk, the Lewes Nodular Chalk, the Seaford Chalk and the Newhaven Chalk.

The lithostratigraphic map of the cliff face indicates that one lithostratigraphic unit occupies about $45 \%$ of the analysed coastline length. The single formations present maybe one of the Lewes Nodular Chalk, the Seaford Chalk or the Newhaven Chalk. About $50 \%$ of the analysed coastline exposes two chalk formations in the cliff, of which the majority comprises Lewes Nodular Chalk and Seaford Chalk 
formations combined (Duperret et al., 2004). Samples have been taken from the three most representative formations, the Lewes Nodular Chalk, the Seaford Chalk and the Newhaven Chalk which together occupy around $90 \%$ of the lithostratigraphic units exposed on the cliff face, in Normandy and Picardy regions.

\subsection{Chalk sampling}

Three types of samples have been obtained for this study. Firstly, two sets of samples were obtained from a $74 \mathrm{~m}$ long core positioned about $60 \mathrm{~m}$ inland from the cliff edge in the Bois de Cise borehole (Lewes and Seaford chalks) (Fig. 1, Fig. 2a). Secondly, chalk blocks were sampled at 1-2 meters above the base of the cliff at Eletot (Lewes Chalk), Dieppe (Seaford Chalk) and Quiberville (Newhaven Chalk). Thirdly, one sample was obtained from the shore platform at Quiberville (Newhaven Chalk). Sampling on the cliff face and on the shore platform was undertaken during January 2002, whereas the coring at Bois de cise was performed during January 2000. The core was stored in a room with a controlled temperature and humidity and was preserved with paraffin-wax and aluminium paper to reduce moisture loss prior to testing. New 25-35 mm diameter cores were obtained from the original borehole core.

\subsection{Macroscopic characteristics of the Chalk}

Field observations show that each chalk formation has a specific lithological character. Numerous marl seams are typical of the Newhaven Chalk Formation, nodularity is typical of the Lewes Nodular Chalk Formation, whereas the Seaford Chalk Formation is more homogeneous and contains bands of large flints. In addition, each formation contains numerous marker-beds and these provide precise stratigraphical information for all the tested samples.

The Eletot samples from the Lewes Nodular Chalk Formation were obtained from beds above the Southerham Marl. At Dieppe, the samples were obtained from the Seaford Chalk Formation, between the Shoreham Marl and the Seven Sisters Flint. The Quiberville samples were obtained from the Newhaven Chalk Formation below the Old Nore Flint Band and lower down on the shore platform. 
Samples of core from the Bois de Cise borehole were taken at $12 \mathrm{~m}$ depth within the Seaford Chalk below the Seven Sisters Flints Band and at $63 \mathrm{~m}$ depth within the Lewes Chalk.

\section{UCS strength tests on natural chalks}

\subsection{Experimental method}

Chalk samples were preserved in sealed bags from the field to the laboratory and sample weighing was performed one day after sampling to reduce the loss of moisture content and to obtain a water content value $(\mathrm{Wn})$ indicative of the natural moisture content of the coastal chalk cliffs, by comparisons with the weight of dry samples. As noted by Lord et al. (2002), evaporation takes place at a very rapid rate once the chalk material is excavated. The measured values of natural moisture content could thus be considered as underestimated. Samples were then stored in an open room at Le Havre, where temperature and atmospheric humidity was roughly the same as in the field. Chalk cores $(25-35 \mathrm{~mm}$ diameter) were obtained perpendicular to bedding. The method of coring was a hand-held tube. Cylinders (30-50 mm length) were prepared, with a ratio of length to diameter (I/d), which ranged from 1.1 to 1.4. Chalk cores were weighed and dried for 48 hours at a temperature of $105^{\circ} \mathrm{C}$, and weighed again to obtain the water content of chalk samples. The values of dry density, degree of saturation, void ratio and porosity were deduced from the density (measured with oil (kerdane) immersion method) and from the water content (Table 1). The natural moisture content $(\mathrm{Wn})$ of each sample range between 9.60 and $22 \%$, that corresponds to degrees of saturation ( $\mathrm{Sr}$ ) of 37 to $70 \%$, respectively. The dry density of the samples varied between 1.46 and $1.65 \mathrm{Mg} / \mathrm{m}^{3}$, which is a range of porosity from $32 \%$ to $46 \%$. According to the intact dry density scale for chalk (Mortimore and Fielding, 1990 ; Matthews et al., 1993 ; Lord et al., 2002), samples described in this paper are low density (dry density lower than $1.55 \mathrm{Mg} / \mathrm{m}^{3}$ ) and the medium density (dry density between 1.55 and $1.70 \mathrm{Mg} / \mathrm{m}^{3}$ ). For Uniaxial Compressive Strength (UCS) tests, dry samples were tested in a computer-controlled uniaxial press, initially dedicated to soil mechanics tests, equipped with a fixed axial load cell with a maximal loading force of $20 \mathrm{kN}$. Chalk cylinders were placed on a platen, that moved upward with a rate ranging between 0.00061 and $1.52 \mathrm{~mm} / \mathrm{min}$. The axial shortening was measured with a displacement transducer of $50 \mathrm{~mm}$ in range. Tests were realised with strain control method, with an 
axial displacement of $0.1 \mathrm{~mm} / \mathrm{min}$. Experiments have shown that the results are unaffected by the method of loading or strain control (Matthews and Clayton, 1993).

Each chalk unit shows the same stress-strain response during the loading stage of uniaxial compression, characterized by brittle behaviour with an axial strain ranging from 0.5 and $1.5 \%$, before failure. The first failure occurs when the peak of maximum compression UCS strength (Rc max) is reached. Rc max is indicative of the UCS strength of the tested sample, whereas the Young's modulus (E) was measured as the maximum slope of the stress-strain curve, just before the failure and is indicative of the sample rigidity (Table 1). Results from natural dry chalk samples show UCS strength ranging between 0.94 and $4 \mathrm{MPa}$ and Young's modulus varying between 1.33 and $4 \mathrm{MPa}$.

During the dry UCS tests, the first failure plane of all the samples is sub-parallel to the cylindrical axis and to the maximum principal stress, cutting the entire core. According to Bahat et al. (2001), such types of failure correspond to a tensile surface. Secondary failures may occur after the first one, but with lower length and with various orientations within the core.

\subsection{UCS strength comparisons between chalk from a borehole and from the cliff face.}

Mechanical tests on chalk samples from two differents locations, i.e. within a borehole located at $60 \mathrm{~m}$ inland from the cliff edge (Bois de cise) and at the base of the cliff face at Dieppe and Eletot.

The highest UCS strengths ( 3 and $4 \mathrm{MPa}$ ) and Young's modulus ( 3.1 and $4 \mathrm{MPa}$ ) have been measured on dry chalk samples from the borehole. As indicated (Fig. 3), both in the borehole and on the cliff face, the Lewes Chalk (lower unit) has a higher UCS strength and Young's modulus than the Seaford Chalk (upper unit). This could be related to the slight difference of chalk formation porosity, with $41-45 \%$ for the Lewes Chalk and $46 \%$ for the Seaford Chalk (Table 1).

The Lewes Chalk located on the cliff face has a UCS strength of the same order as the Lewes Chalk from the borehole, with a slight decrease of the UCS strength (5\%) and of the Young's modulus (11\%). In contrast, the Seaford Chalk from the cliff face has a large reduction of UCS strength (70\%) and Young's modulus (40\%) by comparison with the Seaford Chalk from the borehole.

SEM observations on the Seaford chalk sample located at the base of the cliff at Dieppe has numerous small patches of salt on the rupture surface (Fig. 4a), which may explain the great reduction 
of UCS strength and Young's modulus of this sample (Fig. 3b). As minerals show cubic shapes, we assume that crystals are made of halite $(\mathrm{NaCl})$, as observed on other rocks submitted to salt-spray ageing tests (Cardell et al., 2003) and on chalk sample from south England coastline (Mortimore et al., 2004). The additional precipitation of halite explains the lower porosity of the Seaford Chalk located on the cliff $(34 \%)$, when compared with the higher porosity $(46 \%)$ of the Seaford Chalk in the borehole. This change in porosity could also occur as a result of differences in lithology between the borehole and the cliff. We suggest that this sample has been naturally weathered by sea water wetting or spraying.

SEM observations on the sample of Lewes Chalk from the cliff face (at Eletot) indicates the occurrence of geometrical shapes not related to chalk coccoliths. These are about $50 \mu \mathrm{m}$ in size and appear as ghost structures of cubic minerals (Fig. 4b). This chalk sample shows also a few white cubic patches, with a same size range as the ghost structures. The Lewes Chalk sample from the borehole also shows micro-holes, but they are all located within the fossil shells of the chalk and do not have cubic shapes. The presence of what appears to be salt crystals may explain the slight decrease of the Lewes Chalk strength $(5 \%)$, by comparaison with the Lewes Chalk from the borehole. Ghost structures could originate from salt crystal removal. At Eletot, the sample of Lewes chalk comes from sizeable slabs of rock, that are progressively removed from the cliff face in winter (Fig. 2b). Lautridou et al. (1986) assume that this weathering is induced by freeze/thaw action, favoured by the occurrence of numerous small springs at this location. As SEM observations have also shown a small amount of cubic crystal on the Lewes Chalk at Eletot, we propose that small geometric-shaped holes originate from the removal of an initial halite crystal, due to the freeze/thaw action of water, that may circulate in the initial cracks of the rock. As porosity comparisons indicate a lower porosity for the sample on the cliff face $(33 \%)$ than in the borehole $(41 \%)$ (Table 1), we argue that the process of halite crystallisation induces a local grain to grain rearrangement in the chalk matrix, which may produce local decrease of void spaces. The crystal removal by freeze/thaw action does not change these local rearrangements in the chalk matrix, which keeps a low porosity. 
Comparisons of mechanical properties of chalk samples from the borehole and from the cliff face indicate lower values of UCS strength and Young's modulus for the cliff face chalk samples, where samples are submitted to weathering induced by meteorological changes and sea water wetting.

\subsection{UCS strength comparisons between the cliff face and the shore platform}

In order to investigate the weathering effects on the cliff face and on the shore platform, the Newhaven chalk was sampled at Quiberville at two locations : at the base of the cliff and on the shore platform (Fig. 2a). UCS tests performed on the sample located at the base of the cliff produced a maximum compression strength of $3.46 \mathrm{MPa}$ and a Young's modulus of $3.65 \mathrm{MPa}$, whereas the sample from the shore platform yielded a Rc max of $1.98 \mathrm{MPa}$ and a Young's modulus of $2.53 \mathrm{MPa}$ (Fig. 5). When compared to the cliff face sample, the shore platform sample shows a large decrease of UCS strength (43\%) and Young's modulus (30\%).

SEM observations have not shown distinct salt patches on the sample from shore platform. But, when the sample is magnified 900 times, skeletal pieces of coccoliths appear more distorted and reorganised (Fig. 6). The porosity of the shore platform sample (32\%) is lower than the porosity of the cliff sample (36\%). This difference in porosity could result from different stratigraphic level (lithology) or particle reorganisation due to shore platform weathering by sea water. Hellmann et al. (2002) argue that chemical reactions and transport processes occurring in intergranular regions of the chalk influences rapid free-face dissolution of cement bridges connecting the grains and leads to mechanical failure and concomitant grain-grain sliding. Based on this assumption, the decrease of porosity of the chalk on the shore platform may be explained by grain-grain rearrangements of coccoliths previously weathered.

\subsection{Chalk lithology compared with UCS strength}

A direct comparison between natural chalk sampled at the base of the cliff at Quiberville (Newhaven Chalk) and Eletot (Lewes Chalk) can be made, because field observations have shown that sea-water does not reach the base of the cliff at these locations. The Lewes Chalk appears to have a higher UCS strength $(\mathrm{Rc} \max =3.8 \mathrm{MPa})$ than the Newhaven Chalk $(\mathrm{Rc} \max =3.46 \mathrm{MPa})$, whereas the 
Young's modulus of the Lewes Chalk $(E=3.56 \mathrm{MPa})$ is slightly lower than the Young's modulus of the Newhaven Chalk $(E=3.65 \mathrm{MPa})$. Unfortunatly, as no borehole was located in the Newhaven Chalk Formation in Normandy, the differences of mechanical properties recorded on the samples from the cliff cannot be confidently linked to the initial properties of the chalk units, because differences may also arise from subaerial weathering.

\section{Water effect on chalks}

\subsection{Experimental methods}

Lewes and Seaford Chalk samples from the borehole at Bois de cise were submitted to progressive water saturation so that UCS tests could be carried out at various degrees of saturation. Several methods were used to force the water content into the samples by controlling the negative pore pressure (-Uw) (Fleureau et al., 1993).

A very low negative pore pressure $(-U w<20 \mathrm{kPa})$ corresponds to a very high water content in the sample, with a water content around $30 \%$, which corresponds roughly to the degree of water saturation of the analysed chalk samples. In this case, the tensiometric plates method was used. Chalk samples were placed in atmospheric air pressure conditions on sintered glass tensiometric plates. Water located below the tensiometric plates was submitted to a negative pressure, which caused water to imbibe the sample.

For $50<-U w<1.5 \mathrm{MPa}$, the osmotic technique is used to control the water pressure in the sample. This corresponds to a water content ranging between $15 \%$ and $30 \%$. Samples are placed in the visking dialysis membranes with very small pores $(5 \mathrm{~nm})$ and immersed in solution of Polyethylen Glycol (PEG) 20 000. As the macro molecules tend to hydrate and attract water from the sample, the sample is submitted to negative pressure which depends on the PEG concentration in the solution.

For $2<-U w<1000 \mathrm{MPa}$ (i.e. a very low water content in the sample, which ranges between $15 \%$ and zero), the transfer of water occurs in the vapor phase. Several salt solutions are used to create a very dry area, by controlling the relative humidity of the atmosphere in dessiccators containing the samples, and hence the negative pressure and the water content in the samples, according to Kelvin's law. 


\subsection{Results on chalk samples from the borehole}

The natural moisture content $(\mathrm{Wn})$ of the Lewes and Seaford chalk samples from the borehole at Bois de cise was measured at $27 \%$. This corresponds to a natural degree of saturation ( $\mathrm{Sr}$ ) of $85 \%$ (Seaford Chalk) and 89\% (Lewes Chalk). Six cylindrical core samples from the Seaford chalk (SBDC 1 to 6) and four cylindrical samples from the Lewes chalk (LBDC 1 to 4) were obtained with various degrees of water saturation (Table 2). LBDC samples gave natural moisture contents $(\mathrm{Wn})$ varying from $0.1 \%$ to $18 \%$, which corresponds to a degree of saturation ( $\mathrm{Sr}$ ) from $0.3 \%$ to $60.7 \%$ (Fig. $7 \mathrm{a}$ ). SBDC samples gave natural moisture content $(\mathrm{Wn})$ varying from $0.2 \%$ to $31.7 \%$, which corresponds to a degree of saturation (Sr) from $0.6 \%$ to $100 \%$, respectively (Fig. $7 \mathrm{~b}$ ).

A complete saturation $(\mathrm{Sr}=100 \%)$ was achieved on the Seaford Chalk with a natural moisture content $(\mathrm{Wn})$ of $32 \%$. LBDC and SBDC chalk samples show a similar stress-strain behaviour, characterized by a reduction in UCS strength and Young's modulus of the chalk from dry to saturated conditions (Fig. 7). The decrease of strength ranged from 40 to $50 \%$ of the wet UCS strength of the chalk and this behavior occurred with very low values of natural moisture content, i.e. $\mathrm{Wn}=3 \%$ (Seaford Chalk) and $\mathrm{Wn}=5 \%$ (Lewes Chalk). These water contents correspond to a degree of saturation of $10 \%$ (Seaford Chalk) and $17 \%$ (Lewes Chalk). A chalk sample with a low water content (such as $\mathrm{W}=3 \%$ ) shows roughly the same behaviour as a chalk sample which is completely saturated. Similar behaviour patterns have been observed on other chalk samples, where the water-weakening effects in chalk are most pronounced at $6-10 \%$ water saturation and the effects stabilise at higher saturations (Papamichos et al., 1997). Even 2\% water saturation is sufficiant for chalk to behave as if it were completely water-saturated (Schroeder et al., 1998). These latter examples come from chalk at high confining pressure in oil fields. The decrease of chalk UCS strength of about a twice from dry to saturated conditions has also been noted for chalk samples from England, by various authors (Matthews and Clayton, 1993 ; Bell et al., 1999 ; Mortimore et al., 2004). The water-weakening effect observed during chalk-fluid interactions has been largely discussed in the literature (e.g. Guttierez et al., 2000 ; Hellmann et al., 2002 ; Risnes et al., 2003). From detailed studies conducted on various chalk samples, mechanisms such as capillary effects, chemical effects, physio-chemical effects are proposed to explain the water-weakening effect of chalks. Many of these effects have been reported from chalk oil field investigations. 


\section{Artificial weathering with water and sea water}

\subsection{Experimental method}

In an attempt to assess the durability of chalk submitted to rainfall and sea-water imbibition, laboratory experimental wetting and drying cycles were conducted on various chalk lithologies. As small diameter chalk cylinders are weak to very weak, a short cycle of weathering was chosen to avoid high degradation of the samples before UCS testing. Wetting/drying tests were conducted over 10 days for each sample, with wetting by soaking in water for half-an-hour per day (12 hours) followed by 11 hours of drying. Experiments were conducted on two sets of chalk. The first on a set of chalk cores with distilled water to simulate the wetting/drying effect relative to rainfall and secondly on a second set of chalk cores with salt water (natural sea water from the Channel) to simulate the wetting/drying effect relative to tides at the base of the coastal cliffs. After these short cycles of weathering, no significant macroscopic changes were observed in chalk cylinders. After the 10-days cycle of artificial weathering, chalk cores were dried over a period of 48 hours at a temperature of $100^{\circ} \mathrm{C}$ to finally obtain dry chalk samples with a very low water content. Dry UCS tests have been performed on these dry samples to study the variations of mechanical properties of the chalk after weathering cycles.

\subsection{Effect of water wetting/drying cycles on the chalk.}

For the Lewes Chalk sample from the borehole, the weathering with distilled water produced a decrease of the UCS strength (40\%) and an increase of the Young's modulus (40\%) (Fig. 8a). The same pattern of behaviour was observed on the Lewes Chalk sample from the cliff, with a lower decrease in the UCS strength (33\%) but a greater increase in the Young's modulus (220\%) (Fig. 8b). For the Seaford Chalk from the borehole, the weathering process with distilled water produced a decrease in the UCS strength of $20 \%$ and a increase in the Young's modulus of $60 \%$ (Fig. 9a). The Seaford Chalk sampled at the base of the cliff at Eletot also showed a decrease of UCS strength of $24 \%$ and a increase in the Young's modulus of $43 \%$ (Fig. 9b). 
For the Newhaven chalk sample from the cliff, the weathering process with distilled water produced a decrease of the UCS strength of $47 \%$ and an increase of the Young's modulus of $15 \%$ (Fig. 10a). The Newhaven chalk sample from the shore platform showed a decrease of the UCS strength of $10 \%$ and a increase of the Young's modulus of 100\% (Fig. 10b).

All the chalk samples submitted to a 10 day cycle of weathering with distilled water showed a reduction in UCS strength and increase in Young's modulus, under dry UCS tests.

SEM observations conducted on artificially weathered samples have been compared with their equivalent natural samples, in order to understand the origin of the decrease in UCS results and increase in Young's modulus.

A study of the microfabric of the Seaford Chalk using SEM images before and after artificial weathering suggests the following: (1) disagregation and distortion of the coccoliths, (2) localized compaction (reaggragation) of the coccolith fragments, (3) formation of microcracks (Fig. 11). A similar examination of the Lewes and particularly the Newhaven Chalk samples indicates the same results from cyclic weathering.

Weisbrod et al. (1998) also observed particle detachments on fracture surfaces within a few hours after wetting and drying cycles. This aggregation process can explain the reduction in UCS strength, however it does not explain the increase in Young's modulus.

There are a number of possible causes of increase in Young's modulus, which could also correspond with a decrease in UCS strength. These are : (1) retention of water adsorbed onto crystal surfaces, because normally dried chalk (CP 2001) still contains some water (Piau and Maury, 1994 ; Papamichos et al., 1997, Lord et al., 1998). At such very low water content, water menisci hold the grains together thereby contributing to cohesion, by capillary forces. Flooding with water makes the menisci disappear, and the chalk to become weaker (Delage et al., 1996 ; Guttierez et al., 2000 ; Hellmann et al., 2002 ; Risnes et al., 2003). According to Risnes et al. (2003) the water-weakening effect is related to properties of an adsorbed water layer on the chalk grain surfaces and the degree of weakening depends on the strength of the adsorption of the fluid molecules to the calcite surfaces. This growth of the water layer produces a decrease in strength. When the temperature of water is raised from $0^{\circ} \mathrm{C}$ to $60^{\circ} \mathrm{C}$, it then expands by about $1.5 \%$, exerting a pressure of up to $52 \mathrm{MPa}$ within 
the pores. The expansion and contraction of water in narrow capillaries can produce sufficient pressures to disrupt chalk (Bell, 2000).

Dilatometric studies (Prick, 1996) performed on porous calcareous rocks submitted to 20 cycles of wetting/drying with water have shown a variety of forms of deformation, from the axial center of a core sample to its border. During the first 10 cycles, contraction was measured on the center of the sample and a dilation on its border. This behaviour disappears with a larger number of cycles and it has been explained by a modification of the adsorbed water layer on the pore faces from the center to the border of the sample (Prick, 1996). The wetting/drying process may induce a progressive adsorption of water molecules on the chalk grain surfaces and this may cause the decrease of strength. Prior to reaching an hydraulic balance after the 10 first weathering cycles, the thickness variation of the adsorbed layer from the center to the border of the sample produces a contraction of the central part of the chalk sample, which may induce an increase in Young's modulus. These observations from other calcareous rocks support the results presented here for the chalk. Even if dilatometric forces were not acting within the chalk samples, the increase of the Young's modulus may be explained by anisotropic contraction of the chalk submitted to wetting/drying cycles. Nevertheless, a larger number of weathering cycles needs to be conducted to verify this conclusion.

\subsection{Effect of sea weathering cycles on the chalk}

For the Lewes Chalk from the borehole, the weathering with sea water produced a decrease of the UCS strength (70\%) and the Young's modulus (78\%) (by comparison with the natural sample) (Fig. 8a). The same behavior is observed on the Lewes Chalk from the cliff face (Eletot), with a decrease of UCS strength of $73 \%$ and decrease of Young's decrease of $78 \%$ (Fig. 8b).

The Seaford Chalk from the borehole shows a decrease of UCS strength (60\%) and Young's modulus (38\%) (Fig. 9a). Whereas the Seaford Chalk from the cliff face shows an increase of UCS strength (20\%) and a slight increase in Young's modulus (Fig. 9b). These differences may result from the different position within the Seaford Chalk formation and/or the degree of in situ weathering (increase in salt content) of the chalk sample at Dieppe.

For the Newhaven Chalk from the cliff face, the decrease of UCS strength is $50 \%$ and the Young's modulus has decreased of 38\% (Fig. 10a). The same behaviour is observed for the Newhaven Chalk 
from the shore platform, with a decrease of UCS strength of $28 \%$ and a decrease of Young's modulus of $16 \%$ (Fig. 10b).

These observations indicate that chalk samples submitted to a 10 day cycle of weathering with sea water show the greatest reduction in strength and the lowest Young's modulus.

SEM observations on the Lewes Chalk sample from the borehole (Bois de cise) submitted to artificial weathering with sea-water illustrated numerous salt crusts covering the surface rupture of the sample (Fig. 12). Crystallisation of halite occurs from the salty solution, due to the artificial drying of the sample before UCS testing. As pointed out by Bell (2000), there are three ways whereby salts within a rock can cause it to break down. (1) disruption in rock may take place due to the considerable contrasts in thermal expansion of salts in pores. Halite expands by some $0.5 \%$ from $0^{\circ} \mathrm{C}$ to $60^{\circ} \mathrm{C}$, which may aid rock decay: (2) the pressure produced by halite crystallisation in small pores is up to $200 \mathrm{MPa}$. (3) rehydration exerts an additional pressure that depends on the ambiant temperature and the relative humidity. The thermal expansion and the pressures produced during the crystallisation of halite explain the large decrease of strength and Young's modulus of the samples. The resulting rupture occurs at a lower strength but with increased deformation of the sample.

\subsection{Chalk type sensibility to weathering with fresh and sea water}

After a cycle of weathering with distilled water, the maximum decrease of UCS strength is found in Newhaven Chalk located in the cliff face (47\%), compared with all other chalk lithologies tested, whereas the Newhaven Chalk located on the shore platform shows the lowest decrease of strength (10\%). The decrease of the UCS strength is more important in the Lewes Chalk $(40 \%$ in the borehole and $33 \%$ on the cliff face) than on the Seaford Chalk (20\% on the borehole and on the cliff face). The most sensitive to distilled water wetting/drying is the Newhaven Chalk, followed by the Lewes Chalk and the Seaford Chalk. A direct comparison with porosity values for each sample (Newhaven Chalk : 36\%, Lewes Chalk : $41-45 \%$, Seaford Chalk : $46 \%$ ) indicates that the higher the porosity, the lower the sensitivity to wetting/drying cycles with distilled water. The chalk samples tested, are characterized by high porosity, and they range through the low density scale. Taking into account the process of water- 
layer adsorption on chalk-grain surfaces, we propose that the water layer thickness is linked to the chalk porosity. The lower the porosity, the easier the adsorption of the water layer on to chalk-grains.

When different chalk lithologies are submitted to artificial weathering with sea water, the most sensitive to sea weathering is the Lewes Chalk (70 to $73 \%$ decrease in strength), followed by the Seaford Chalk (60\% decrease in strength) and the Newhaven Chalk (50\% decrease in strength). In contrast to the results from distilled water weathering cycles, no direct link can be proposed between the unweathered chalk porosity and decrease of strength in salt weathered chalk. This is because the salt has crystallised in the chalk matrix and this will reduce porosity and change density. The number of micro-cracks may vary between samples and this may induce a change in the fissure porosity of each sample. Unfortunatly, the discrimination between pore and fissure porosity is not apparent in the experimental methods used in this paper.

Even if all chalk samples show the same behaviour under a cycle of weathering with fresh and sea water, they do not show the same sensitivity to the weathering type. In the natural environement, chalk weathering is not only linked to the duration of atmospheric weathering (rain, frost, sun) and marine (salt) agents, but the effect of wetting/drying cycles by fresh water is also linked to chalk lithology (assumed to be linked to the chalk porosity). There is, however great uncertainty about the effect of sea-water and salt crystallisation on chalk mechanical behaviour.

\section{Weathering on coastal chalk cliffs}

As noted by Lord et al. (2002), strengths of chalk has a wide range of UCS strength varying from as little $0.7 \mathrm{MPa}$ to as much as $40 \mathrm{MPa}$. The heterogeinity of chalk properties has been revealed on each chalk unit, at various scales, even inside a small chalk sample of $0.2 \mathrm{~m}$ long (Mortimore and Pomerol, 1998). Our results are based on the analysis of one chalk sample for each experiment. Even if comparisons have been made between the same chalk units, special local conditions may have affected the results. Further analysis is required to have full confidence in the results so far. Nevertheless, these results provide a first insight into the impact of chalk weathering under controlled conditions on mechanical properties. 
Based on dry UCS tests (Anon 1977), the chalk samples presented in this paper are classified as weak rocks, with Rc max ranging between 1.98 to $4 \mathrm{MPa}$. Dry UCS tests measured on Upper Chalk from the Paris basin in north and north-west France also give low strength values ranging from 1.34 MPa to 9.17 MPa in Somme region (Masson, 1973), which classify these latter chalk samples as weak and moderatly weak rocks (Anon 1977). However, Dry UCS tests measured on Upper chalk samples from England show higher values than chalk in France. It is the case for chalk samples from Yorkshire, Norfolk and Kent regions with mean values of $25 \mathrm{MPa}, 9.5 \mathrm{MPa}$ and $5.5 \mathrm{MPa}$ respectively (Bell et al., 1999) and for chalk samples from south east England region, with values ranging from $6 \mathrm{MPa}$ to 19 MPa (Mortimore et al., 2004). It should be noted that the french samples given in this paper were of smaller dimensions (25-35mm diameter) than samples from the UK (e.g. Mortimore et al., 2004, 39-54 $\mathrm{mm}$ diameter). There could, therefore, be scale effects causing differences in the results obtained from France and England, perhaps explaining the consistently lower strength values from France. Size of sample is probably important in chalk because of the inhomogeneities such as shells of different sizes, nodule formation and burrows, as well as microcracks. Consequently, larger diameters cores with the correct I/d ratio (i.e. greater than 2 and less than 4) may give more reliable results.

As physical properties of chalk rocks present large variations from place to place, the role of weathering on chalk rocks in coastal environment needs to be specified in order to better define changes in physical properties of chalk and constrain modelling of coastal chalk cliff instability.

Strength comparisons between chalk samples from a borehole and from the base of the cliff face show a decrease of UCS strength of $5 \%$ and $70 \%$ respectively. This discrepancy is assumed to be indicative of the weathering variability on coastal cliffs. Chalk located at the base of the cliff face is submitted to various environmental conditions that primarly depend on the height of the shore platform and the height of sediments accumulated on the beach located at the toe of the cliff (Brossard and Duperret, 2004). Where the height of the shore platform and sediments is a few meters above the mean sealevel, sea-water does not reach the base of the cliff even during high tide, but spray of sea-water may occur at the base of the cliff. Where the shore platform height is around the mean sea-level, sea-water may reach the base of the cliff during high tide and the cliff base is continuously saturated. Thus, the variations of mechanical properties of the chalk at the base of the cliff face is closely linked to the local 
morphological conditions of the coastline. In the field, coastal cliffs reached by sea water appear clean white, with a smooth morphology, such as at Quiberville. We assume that where the sea may reach the base of the cliff every six and a half hours, salt crystallisation cannot occur due to continuously wet conditions.

At Dieppe, the sea does not reach the base of the cliff due to the thickness of the shingle on the beach at Dieppe. In this case, sea water sprays may reach the cliff and salt may crystallise more easily due to dry conditions in the cliff, as observed experimentally by Cardell et al. (2003). This salt crystallisation contribute to a large decrease of chalk UCS strength and Young's modulus, as observed on the Seaford Chalk.

At Eletot, the sea does not reach the base of the cliff, but subaerial processes such as rain and frost, contribute to weathering the chalk. In this case, the decrease of mechanical properties in the Lewes chalk is very low.

Strength comparisons between Newhaven Chalk sample on the cliff face and on the shore platform show a decrease of strength of $43 \%$. Even if the strength decrease needs to be confirmed on other chalk lithologies, it appears that weathering effects are more important on the shore platform than on the cliff face. Subaerial weathering induced by wetting and drying tidal cycles has been proposed as the main process acting on the developement of shore platforms, because it induces a reduction of rock compressive strength (Stephenson and Kirk, 2000). During low tide, the chalk material does not completely dry, due to the temperate atmospheric conditions in Normandy. In fact, the shore platform is rarely dry at low tide and the salt in solution cannot crystallise. Thus, the strength reduction of the chalk located on the shore platform may be linked to the weathering of the coccoliths by disaggragation, which produces a grain-grain rearrangement in the chalk matrix. In contrast, as observed on the cliff at Dieppe, salt may crystallise more easily in the cliff face because the chalk may dry during low tide, especially during windy and/or sunny conditions.

Experiments on three chalk units show that hydration produces a marked decrease of UCS strength, which varys depending on the chalk type (47\% on the Newhaven Chalk, 33 and $40 \%$ on the Lewes Chalk, $20-24 \%$ on the Seaford chalk). The wetting/drying effect may also be considered as weathering process on chalk submitted to ground water level fluctuations. The magnitude of the water table 
fluctuations in the Paris Basin is generally inversely proportional to the degree of fissuring (i.e. low permeability areas, with less fractures have high water table fluctuations). The amplitude of the longterm range of variations (10-30 years) is often large, of the order of 10-15m in Normandy and Picardy, but the seasonal variations are in the range of a few meters (Crampon et al., 1993). Hydration by wetting/drying needs to be considered as a long-term chalk weathering process. This process could be measured in the natural environment because it can be precisely correlated with piezometry. Having carried out dry strength tests after the wetting and drying cycles it is evident that dry chalk is weakened by the cyclic weathering process. This provides a possible explanation for triggering of several large coastal collapses in Normandy during a warm dry summer (July and August 2001) following an extreme wet period the previous year (Duperret et al., 2004) .

As the water content of a chalk sample has a direct water-weakening effect on strength of $40-50 \%$ reduction, it has been widely suggested that it is a triggering mechanism for chalk cliff collapses following periods of heavy rainfall. In the natural environment, the division between the waterweakening effect and the wetting/drying effect appears difficult to determine in the case of cliff collapses occurring during or after rainfall periods (in contrast to the dry chalk cliff failures discussed above).

Salt weathering induces the highest decrease of strength properties (52-70\%). In coastal environment, especially during windy and/or stormy conditions, spray of sea-water may be able to reach all the height of the cliff face to produce weathering by salt crystallisation within the chalk. However, the thickness of chalk weathering on the cliff face is poorly known. We argue that salt weathering is mainly surficial, because even if sea-water may penetrate within the chalk massif by means of fissures or voided karsts, thermic conditions within the karsts are not so warm to allow drying of the solution and salt crystallisation.

\section{Conclusions}

UCS strength results from the chalk vary as a function of several parameters, as follows: chalk lithology, location of the sample on the coastline and water content of the chalk unit. 
(1) The chalk lithology depends on the conditions of rock formation (sedimentation, climatic conditions...) and the structural history of the region.

Dry UCS tests conducted on three chalk units sampled in Upper Normandy indicate very low values of UCS strength varying between $3.46 \mathrm{MPa}$ and $4 \mathrm{MPa}$ (i.e. very weak rocks). The Lewes Chalk presents the highest UCS strength (4MPa), the Newhaven Chalk appears to be weaker (with a maximum strength of $3.46 \mathrm{MPa}$ ), but with an increased Young's modulus of $3.65 \mathrm{MPa}$ ) and the Seaford Chalk is the weakest (UCS strength: $3 \mathrm{MPa}$ and Young's modulus: $3.1 \mathrm{MPa}$ ).

(2) Chalk strength variations are closely linked to chalk sample locations on the coastline. The geatest decrease of chalk UCS strength is recorded at the base of a cliff not reached by sea-water during high tide, but where spray of sea-water may occur. The decrease of strength $(70 \%)$ is produced by halite crystallisation within the chalk. A lower decrease of chalk strength $(40 \%)$ is recorded on the shore platform, where the chalk matrix is weathered by sea-water, but with no salt crystallisation. The lowest decrease of chalk strength (5\%) is observed at a cliff base affected by aerial weathering only and where fresh water is produced from springs.

(3) The water content of the chalk varies with fluctuations of groundwater level. When chalk samples are submitted to a progressive water wetting, a fall of strength occur. The decrease of UCS strength and Young's modulus is between 40 to $50 \%$ of the dry strength of chalk and this reduction begins with very low values of water content within the chalk (i.e. from $3 \%$ for the Seaford Chalk and $5 \%$ for the Lewes Chalk). This corresponds to a degree of saturation ( $\mathrm{Sr}$ ) of $10 \%$ and $17 \%$, respectively.

(4) Artificial cycles of weathering conducted in the laboratory on chalk, and SEM observations on weathered samples, provide a method of determining the degree of weathering produced by each cycle.

When the chalk is submitted to a 10 days cycle of weathering with distilled water, all chalk samples show a reduction in strength (from $20 \%$ to $47 \%$ ) and an increase in Young's modulus (from $15 \%$ to $220 \%$ ). SEM observations have shown that this reduction of strength may be due to the occurrence of microcracks and particle disaggregation in the sample and to a probable detachement of particles from the rupture surface of the weathered samples. 
Two processes appear to be the dominant influence on chalk strength in the coastal environment. Firstly, natural alternations of wetting and drying on the chalk, due to climatic conditions in the field, may have an influence on the strength of the chalk. Nevertheless, the strength reduction appears less important than the direct effect of water saturation of the chalk pores. Secondly, when the chalk samples are submitted to 10 day cycles of wetting and drying with sea water, the chalk strength and the Young's modulus are the lowest, with a decrease of strength ranging from $52 \%$ to $73 \%$ and a decrease of Young's modulus from $16 \%$ to $78 \%$. This reduction of strength and Young's modulus is due to salt crystallisation in the chalk. Salt crystallisation appears to be the most important process of weathering of the chalk in the coastal environment.

\section{Acknowledgments}

This study has been financially supported by the "Région Haute-Normandie", by means of a post doctoral fellowship (MD). We thank Laurent Bizet for the kindly assistance during SEM analysis and Anouk Duceux, that help us to perform chalk cutting and wetting/drying tests on chalk. One part of chalk samples used in this paper provide from a borehole, that was performed at Bois de Cise, during the ROCC project funded by the European community through the INTERREG II Rives-Manche initiative (contract 199059).

\section{References}

Anon 1977, The description of rock masses for engineering purposes. Working Party Report, Quaterly Journal Engineering Geology, 10, p. 355-388.

Bahat D., Rabinovitch A., Frid V., 2001, fracture characterization of chalk uniaxial and triaxial tests by rock mechanics, fractographic and electromagnetic radiation methods. Journal of Structural Geology, 23, p. 1531-1547.

Bell F.G., Culshaw M.G., Cripps J.C., 1999, A review of selected engineering geological characteristics of English Chalk, Engineering Geology, 54, p. 237-269.

Bell F.G., 2000, Engineering properties of soils and rocks, fourth edition, Blackwell Science, 475p. 
Brossard J. and Duperret A., 2004, Coastal chalk cliff erosion : experimental investigation on the role of marine factors. in : Mortimore R.N. and Duperret A. (eds), Coastal Chalk Cliff Instability, Geological Society, London, Engineering Geology Special publications, 20, p. 109-120

Cardell C., Rivas T., Mosquera M.J., Birginie J.M., Moropoulou A., Prieto B., Silva B. \& Van Grieken R., 2003, Patterns of damage in igneous and sedimentary rocks under conditions simulating sea-salt weathering. Earth Surface Processes and Landforms, 28, p. 1-14.

Costa, S., 2000, Le recul des falaises du pays de Caux, Bulletin d'Information des Géologues du Bassin de Paris, $37, n^{\circ} 1$, p. 31-34.

Crampon N., Le Roux J.C. \& Bracq, 1993, France, in : Downing R.A., Price M. \& Jones G.P. (eds), The Hydrogeology of the Chalk of North-West Europe, Oxford University Press, pp 113-152.

Delage P., Cui Y.J. \& Schroeder C., 1996, subsidence and capillary effects in chalks. Eurock '96, ISRM International symposium. Torino, Italy, pp. 1291-1298.

Dornbusch, U., Williams, R.B.G., Robinson, D.A. \& Moses, C., 2001, Disappearing act : Contribution of cliff erosion and in situ abrasion of flint to the shingle budget on the East Sussex coast, European Rock Coasts 2001 conference, Brighton, UK, 17-18 December 2001.

Duperret, A., Genter, A., Mortimore, R.N., Delacourt, B., \& De Pomerai, M., 2002, Coastal rock cliff erosion by collapse at Puys, France : the role of impervious marl seams within chalk of NW Europe. Journal of Coastal Research, vol.18, n¹, p. 52-61.

Duperret, A., Genter A., Martinez A. \& Mortimore, R.N., 2004, Coastal chalk cliff instability in NW France: role of lithology, fracture pattern and rainfall. in : Mortimore R.N. and Duperret A. (eds), Coastal Chalk Cliff Instability, Geological Society, London, Engineering Geology Special publications, 20, p. 33-55.

Fairbridge R.W., 1968, The Enceclopedia of Geomorphology, Encyclopedia of Earth Sciences series vol. III, ed. Rhodes W. Fairbridge, Reinhold Book corporation New York, 1295 pp.

Fleureau, J.M., Kheirbek-Saoud, S., Soemitro, R., \& Taibi, S., 1993, Behavior of clayey soils on drying-wetting paths, Canadian Geotechnical Journal, vol. 30, n², pp. 287-296

Genter A., Duperret A., Martinez A., Mortimore R.N., Vila J-L., 2004, Multiscale fracture analysis along the French chalk coastline for investigating cliff collapse erosion. in: Mortimore R.N. and Duperret A. (eds), Coastal Chalk Cliff Instability, Geological Society, London, Engineering Geology Special publications, 20, p. 57-74 
Gutierrez M., Oino L.E., Hoeg K., 2000, The effect of fluid content on the mechanical behaviour of fractures in Chalk, Rock Mechanics and Rock Engineering, 33 (2), p. 93-117.

Hellmann R., Renders P., Gratier J-P., \& Guiguet R., 2002, Experimental pressure solution compaction of chalk in aqueous solutions. Part 1. Deformation behavior and chemistry. in : R. Hellmann \& S.C. Wood (eds). Water-Rock interactions, Ore deposits, and Environmental Geochemistry : A tribute to David A. Crear, The Geochemical Society, Special Publication $n^{\circ} 7$, p. $129-152$.

Lahousse P. \& Pierre G., 2003, The retreat of chalk cliffs at cape Blanc-Nez (France): Autopsy of an erosional crisis, Journal of Coastal Research, 19, 2, p. 431-440.

Lautridou J.P., Letavernier G., Lindé K., Etlincher B. \& Ozouf J.C., 1983, Porosity and frost susceptibility of flints and chalk: laboratory experiments, comparison of 'glacial' and 'periglacial' surface texture of flint materials, and field investigations. in : G. de G. Sieveking and M.B. Hart (eds), The scientific study of flint and chert, Proceedings of the fourth international flint symposium held at Brighton Polytechnic 10-15 april 1983, Cambridge University Press. p. 269-282.

Lord C.J., Rhett D.W.\& Johlman C.L., 1998, Is capillary suction a viable cohesive mechanism in chalk. Proc. Eurock '98, Trondheim, Norway, pp. 367-375.

Lord, J.A., Clayton, C.R.I. \& Mortimore, R.N., 2002, The engineering properties of chalk. Construction Industry Research and Information Association (CIRIA), London, Report 000-2001, 279 p.

Masson M., 1973, Pétrophysique de la craie. in: La Craie, Bulletin de liaison des Laboratoires des Ponts et Chaussées, spécial V, pp. 23-47.

Matthews M.C. \& Clayton C.R.I., 1993, Influence of intact porosity on the engineering properties of a weak rock. in: Anagnostopoulos A., Sclosser F., Kalteziotis N., Frank R. (eds). Geotechnical Engineering of hard soils - weak rocks. Balkema Rotterdam. 1. Pp. 693-702.

Matthews, M.C, Clayton, CRI \& Russel, C.S, 1993, Assessing the mass compressibility of chalk from visual description. In : Proc. Engg Grp of Geol Soc Conf on the Engg Geol of Weak Rocks, Leeds, 1990. AA Balkema, Rotterdam, pp 351-368.

Mortimore, R.N., 1983, The stratigraphy and sedimentation of the Turonian-Campanian in the Southern Province of England. Zitteliana, 10, p. 27-41. 
Mortimore R.N., 1986, Stratigraphy of the Upper Cretaceous White Chalk of Sussex. Proceeding of the Geologist's Association. Vol. 97, 97-139.

Mortimore, R.N., 2001, ROCC project, Report on mapping of the chalk Channel coast of France from Port du Havre-Antifer to Ault, June-September 2001, unpublished report for BRGM, 20p.

Mortimore, R.N., \& Fielding P.M., 1990, The relationship between texture, density and strength of chalk. In : Chalk. Thomas Telford, London, pp. 109-132.

Mortimore, R., N., \& Pomerol, B., 1998, Basin analysis in engineering geology: chalk of the AngloParis Basin. In: D., Moore, \& O., Hungr, (eds), Proceedings, Eight International Congress, International Association for Engineering Geology and the Environment, Balkema, Rotterdam. pp 3249-3268.

Mortimore R.N., Stone K.J., Lawrence J., Duperret A., 2004, Chalk physical properties and cliff instability. in : Mortimore R.N. and Duperret A. (eds), Coastal Chalk Cliff Instability, Geological Society, London, Engineering Geology Special publications, 20, p. xx-xx.

Papamichos E., Brignoli M., Santarelli F.J., 1997, An experimental and theorical study of partially saturated collapsible rock, Mechanics of Cohesive-frictional Materials, 2, (3), p. 251-278.

Piau J.M. \& Maury V., 1994, Mechanical effect effects of water injection in chalk reservoirs. Proceedings Eurock' 94 SPE/ISRM Int. Conference. Pp. 819-828.

Prick A., 1996, La désagrégation mécanique des roches par le gel et l'haloclastie. application de la méthode dilatométrique et mise en relation avec le comportement hydrique et les caractéristiques physiques des échantillons. Thèse de Doctorat en Sciences Géographiques, Université de Liège, Belgique. 293p.

Risnes R., Haghighi H., Korsnes R.I. \& Natvik O., 2003, Chalk-fluid interactions with glycol and brines, Tectonophysics, 370, p. 213-226.

Schroeder C., Bois A.P., Maury V. \& Hallé G., 1998, Water/chalk (or collapsible soil) interaction: Part II. Results of tests in laboratory on Lixhe chalk to calibrate water/chalk models. Eurock '98. Trondheim, Norway, 2, p. 505-514 (SPE 47587)

Stephenson W.J. \& Kirk R.M., 2000, Development of shore platforms on Kaikoura Peninsula, South Island, New Zealand. II: the role of subaerial weathering. Geomorphology, 32, 43-56.

Sunamura, T., 1992, Geomorphology of Rocky coasts, John Wiley and Sons, 293 p. 
Weisbrod, N., Nativ, R., Ronen, D. \& Adar, E., M., 1998, On the variability of fracture surfaces in unsaturated chalk, Water Resources Research, 34, 1881-1887. 


\section{Table Captions}

Table 1:

Mechanical characteristics of chalk samples from the cliff and from the beach platform. Natural: without artificial weathering. DW : weathering with distilled water. SW : weathering with sea water. ${ }^{*} \mathrm{Sr}$ $=(\gamma s . W n) / e, \gamma d=\gamma /(1+W n), e=(\gamma s-\gamma d) / \gamma d$, with $\gamma s=$ specific gravity of calcile $(2,7), n=e /(1+e)$.

Table 2 :

Mechanical characteristics of chalk samples from the borehole (Lewes Chalk, Seaford Chalk), with various imposed moisture content. ${ }^{*} \mathrm{Sr}=(\gamma \mathrm{s} . \mathrm{W}) / \mathrm{e}, \quad \gamma d=\gamma /(1+\mathrm{W}), \quad \mathrm{e}=(\gamma \mathrm{s}-\gamma \mathrm{d}) / \gamma \mathrm{d}$, with $\gamma \mathrm{s}=$ specific gravity of calcile $(2,7), n=e /(1+e)$.

\section{Figure Captions}

Figure 1:

Synthetic geological section of the coastal chalk cliffs of Upper-Normandy and Picardy, France, with detailed chalk lithostratigraphic formations used in this paper. * This scale of chalk formations is somewhere used in the English literature and the correspondance with the lithostratigraphic scale is given. The location of chalk sampling is indicated. F1 : Fécamp-Lillebonne fault, F2 : Bray fault.

\section{Figure 2:}

A. Schematic cross section of a coastal chalk cliff, with chalk sampling location. Not to scale.

B. Photographs of the base of the analysed chalk cliff, at each location of sampling, with indications of local lithostratigraphic key-markers.

Figure 3:

Dry UCS tests on natural chalk samples. A :Comparisons between chalk samples from a borehole at Bois de cise (Lewes Chalk and Seaford Chalk). B : Comparisons between chalk samples from the base of the cliff face (Lewes Chalk at Eletot and Seaford Chalk at Dieppe) 
Figure 4:

SEM observations of the rupture surface on natural samples after dry UCS test.

A : Lewes Chalk from the cliff face (Eletot). Occurrence of small distincts geometrical ghost structures. Magnification : left: $\times 35$, right: $\times 350, \times 600$.

B. Seaford Chalk (from the base of the cliff at Dieppe). Occurrence of small salt patches.

Magnification : left : $\times 35$, right : $\times 600$

Figure 5:

Dry UCS tests on natural Newhaven Chalk samples from Quiberville, located on the cliff face and on the shore platform.

Figure 6:

SEM pictures of the rupture surface after dry UCS tests on natural samples. Magnification : $x 900$. Comparisons of Newhaven Chalk samples providing from the base of the cliff (left) and from the shore platform (right) at Quiberville. Skeletal pieces of coccoliths are more distorted on the shore platform sample than on the cliff face.

Figure 7:

Dry UCS tests on natural samples, with various degree of water saturation imposed with moisture content control methods. A: Lewes chalk from the borehole (Bois de cise). B: Seaford chalk from the borehole (Bois de cise). W : imposed moisture content.

Figure 8:

Dry UCS tests on Lewes Chalk samples. Natural chalk samples are reported in black and chalk samples artificially weathered with distilled water are reported in grey and chalk samples artificially weathered with sea water are reported in white.

A: Dry UCS tests on the Lewes Chalk sample from the borehole at Bois de cise

B: Dry UCS tests on the Lewes Chalk sample from the base of the cliff face at Eletot.

Figure 9: 
Dry UCS tests on Seaford Chalk samples. Natural chalk samples are reported in black and chalk samples artificially weathered with distilled water are reported in grey and chalk samples artificially weathered with sea water are reported in white.

A: Dry UCS tests on the Seaford Chalk sample from the borehole at Bois de cise

B: Dry UCS tests on the Seaford Chalk sample from the base of the cliff face at Dieppe.

Figure 10:

Dry UCS tests on Newhaven Chalk samples. Natural chalk samples are reported in black and chalk samples artificially weathered with fresh water are reported in grey and chalk samples artificially weathered with sea water are reported in white.

A: Dry UCS tests on the Newhaven Chalk sample from the base of the cliff face at Quiberville.

B: Dry UCS tests on the Newhaven Chalk sample from the shore platform at Quiberville.

Figure 11:

SEM observations on chalk samples artificially weathered with distilled water.

A: Seaford Chalk sample from the borehole (Bois de cise). Magnification: x350. Natural sample (top) and sample artificially weathered with small cracks (down).

B. Lewes Chalk sample from the cliff face (Eletot). Magnification: x120. Natural sample (top) and sample artificially weathered with skeletal pieces of coccoliths reorganisation (down).

Figure 12:

SEM observations on the Lewes Chalk sample from the borehole (Bois de cise), submitted to a 10 days artificial cycle of weathering with sea water, with various magnifications: x35 (top), x600 (down). Occurrence of large patches of salt crystal (halite). 

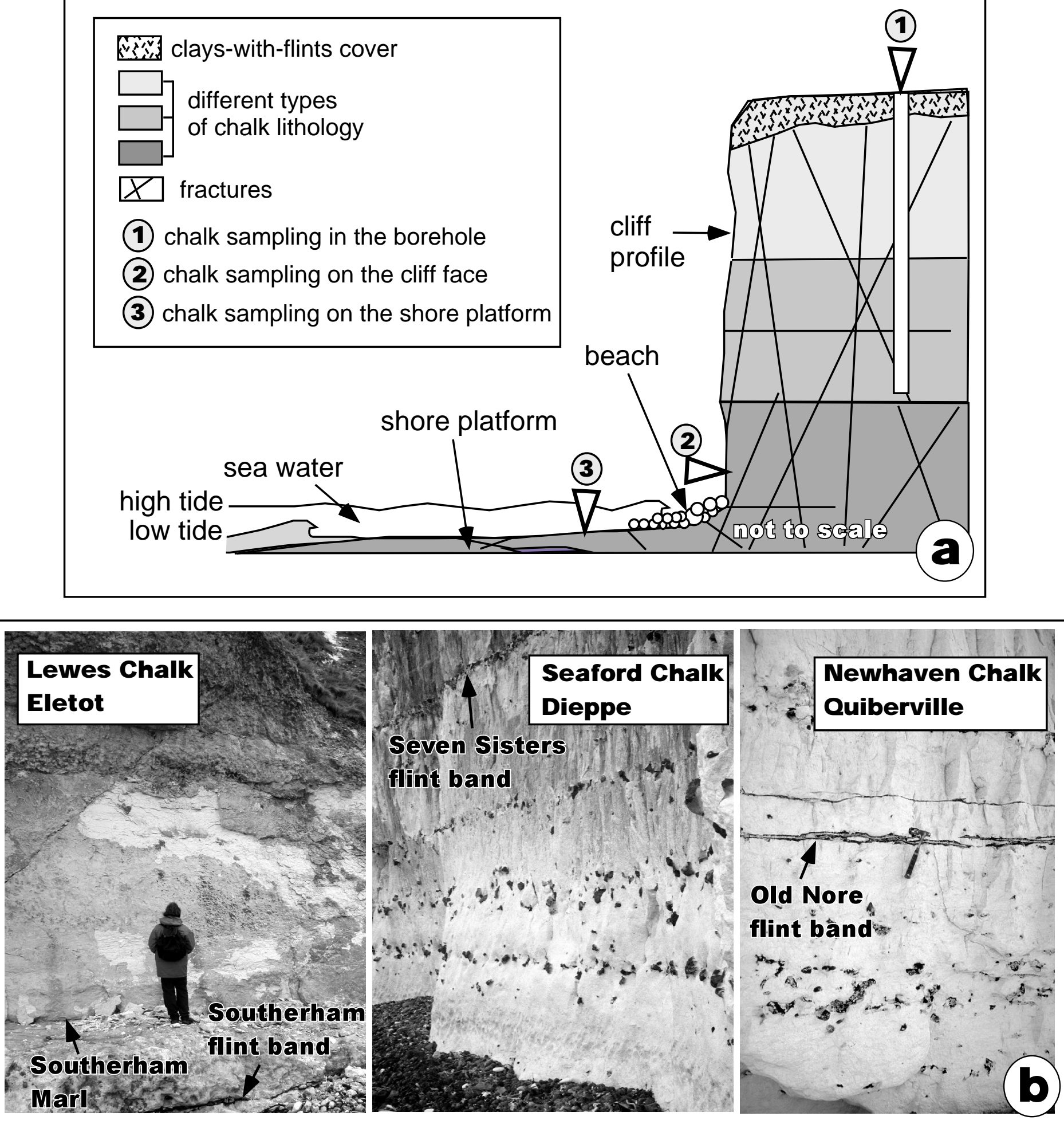


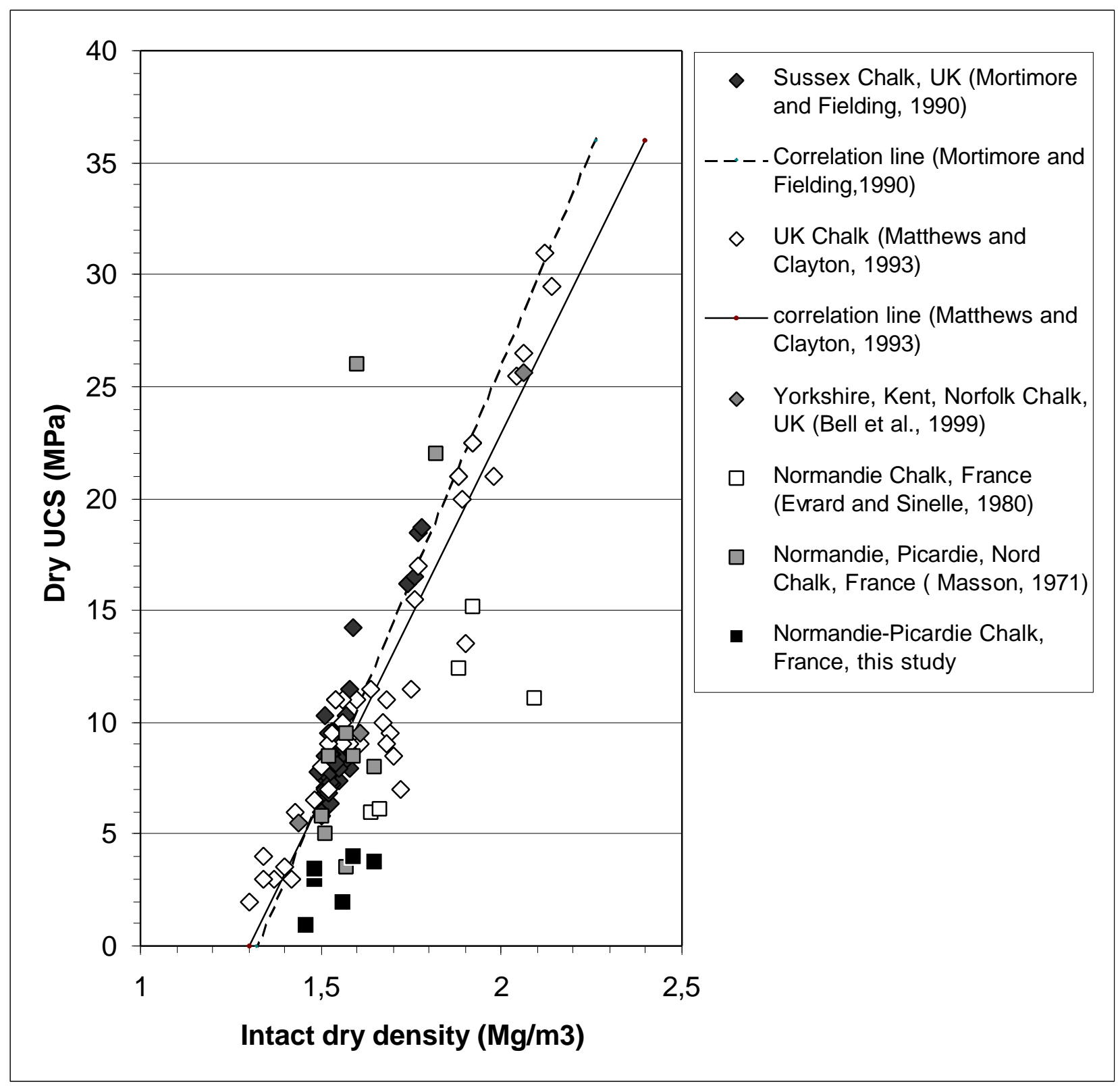



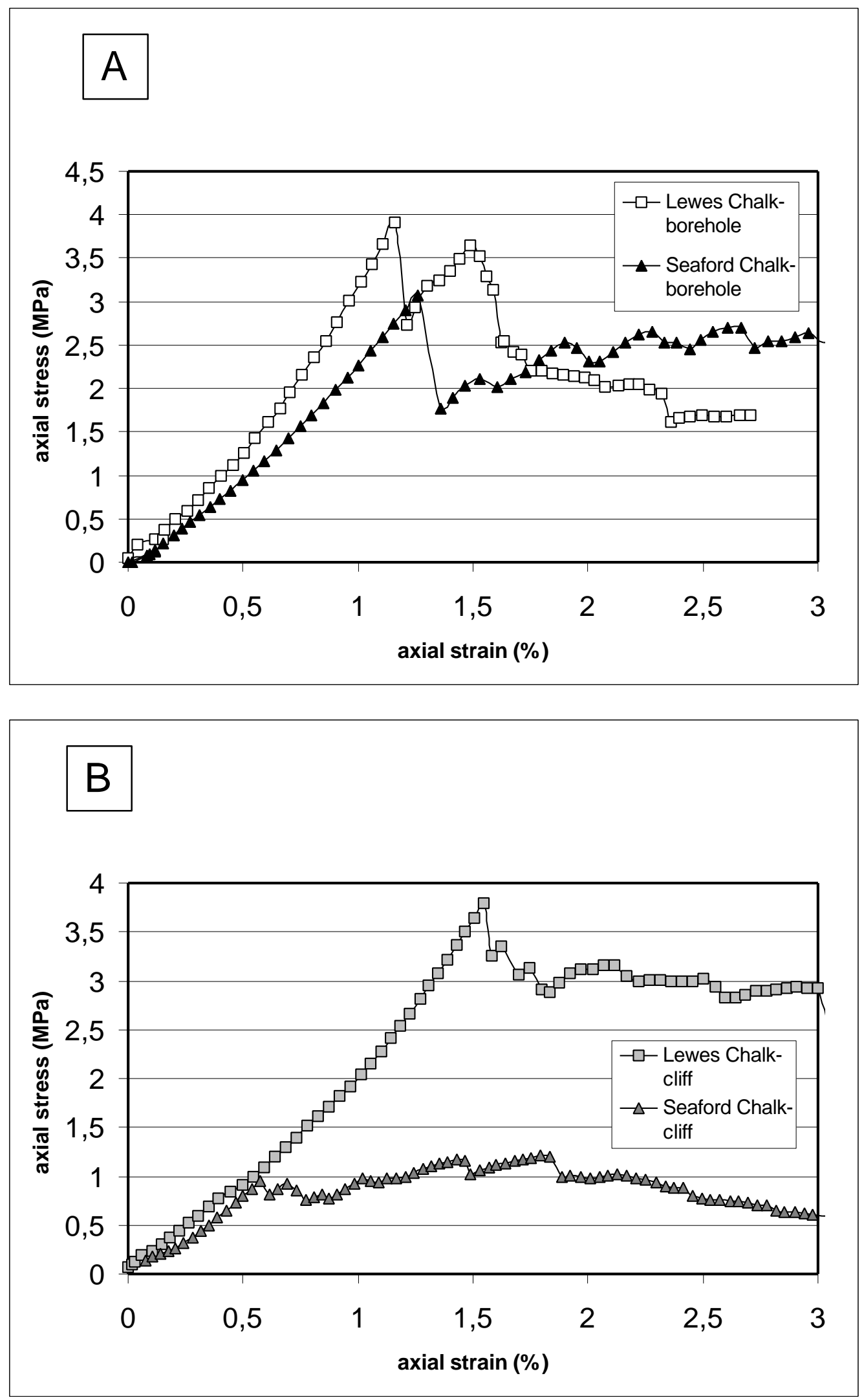

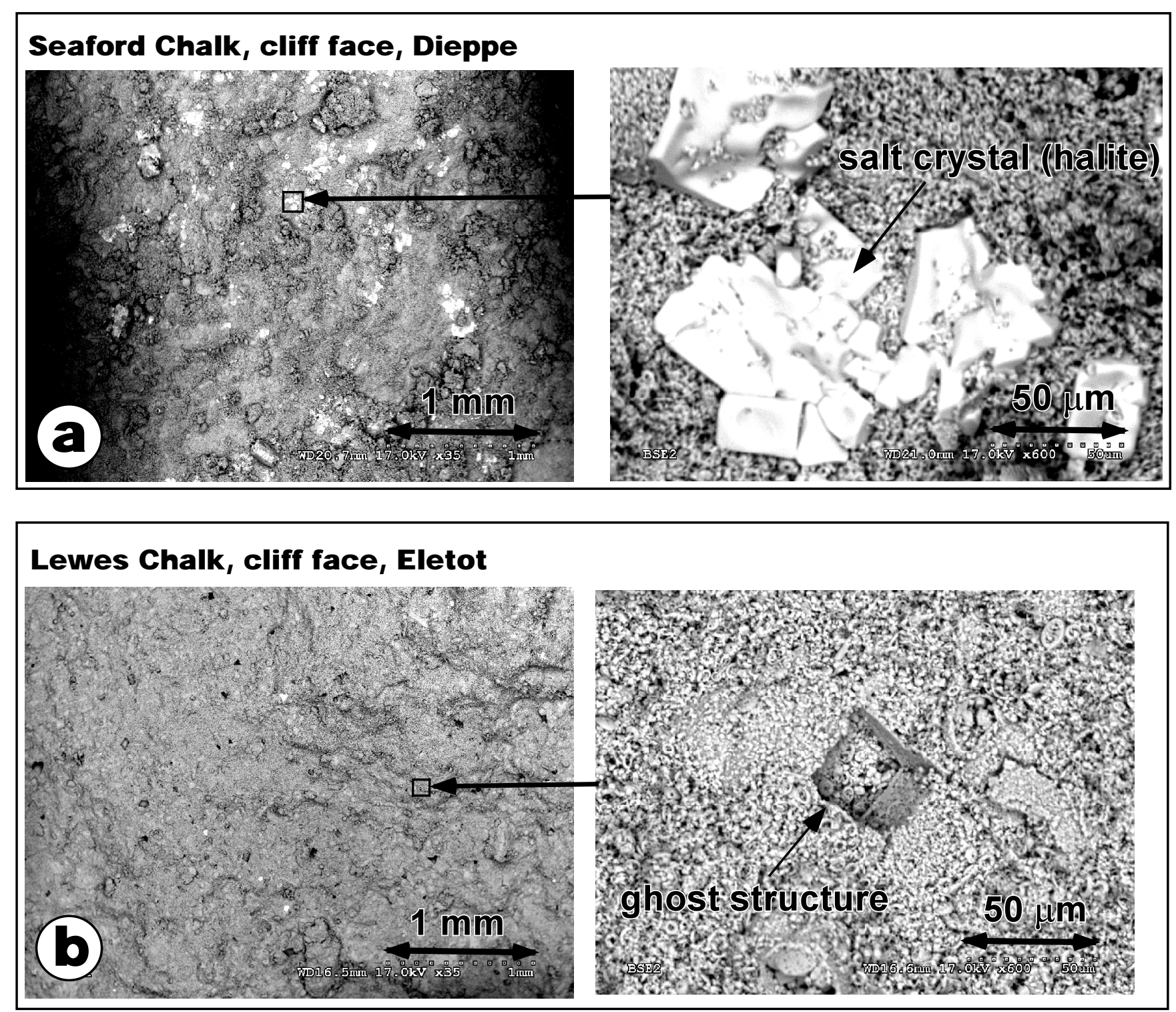


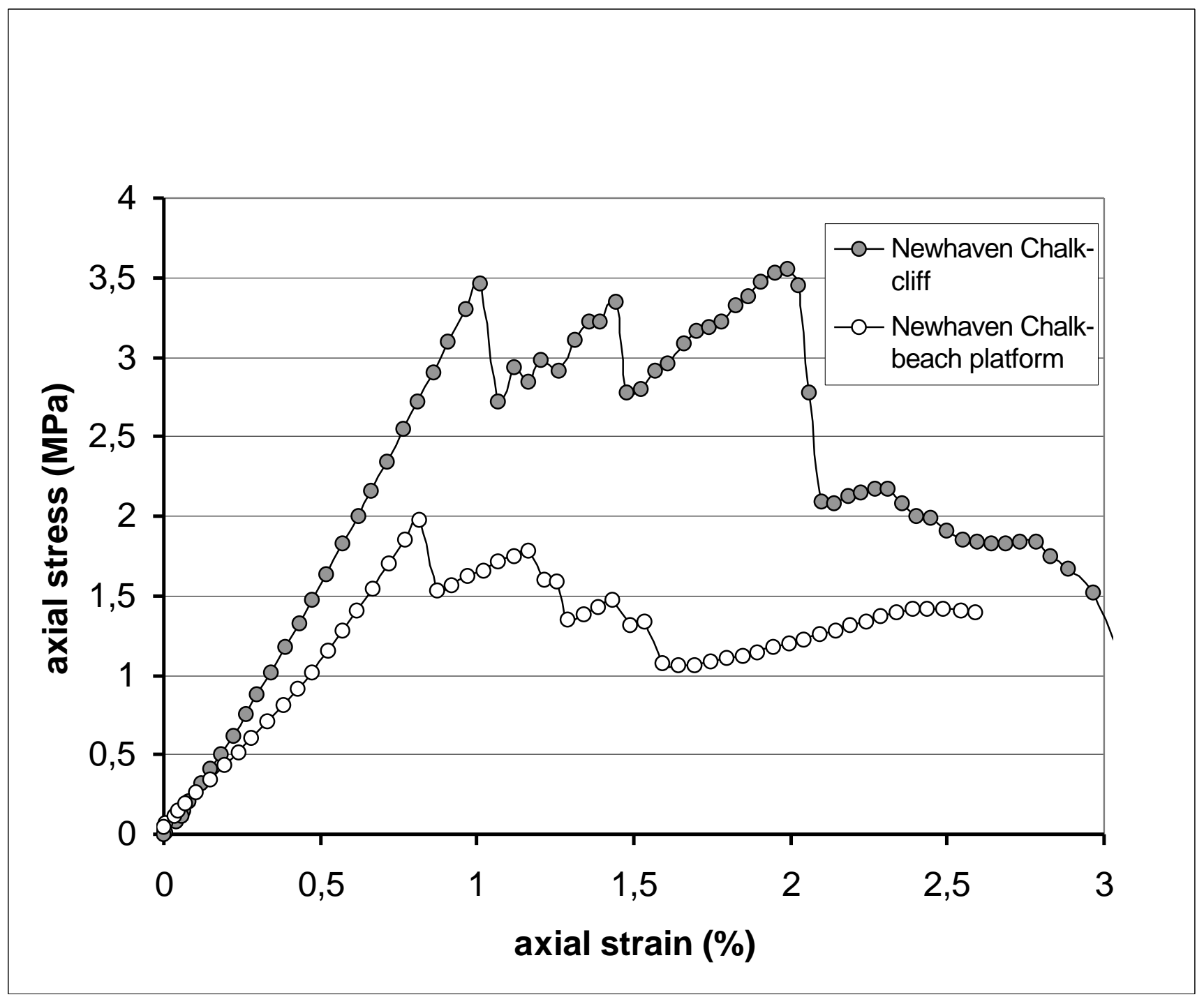




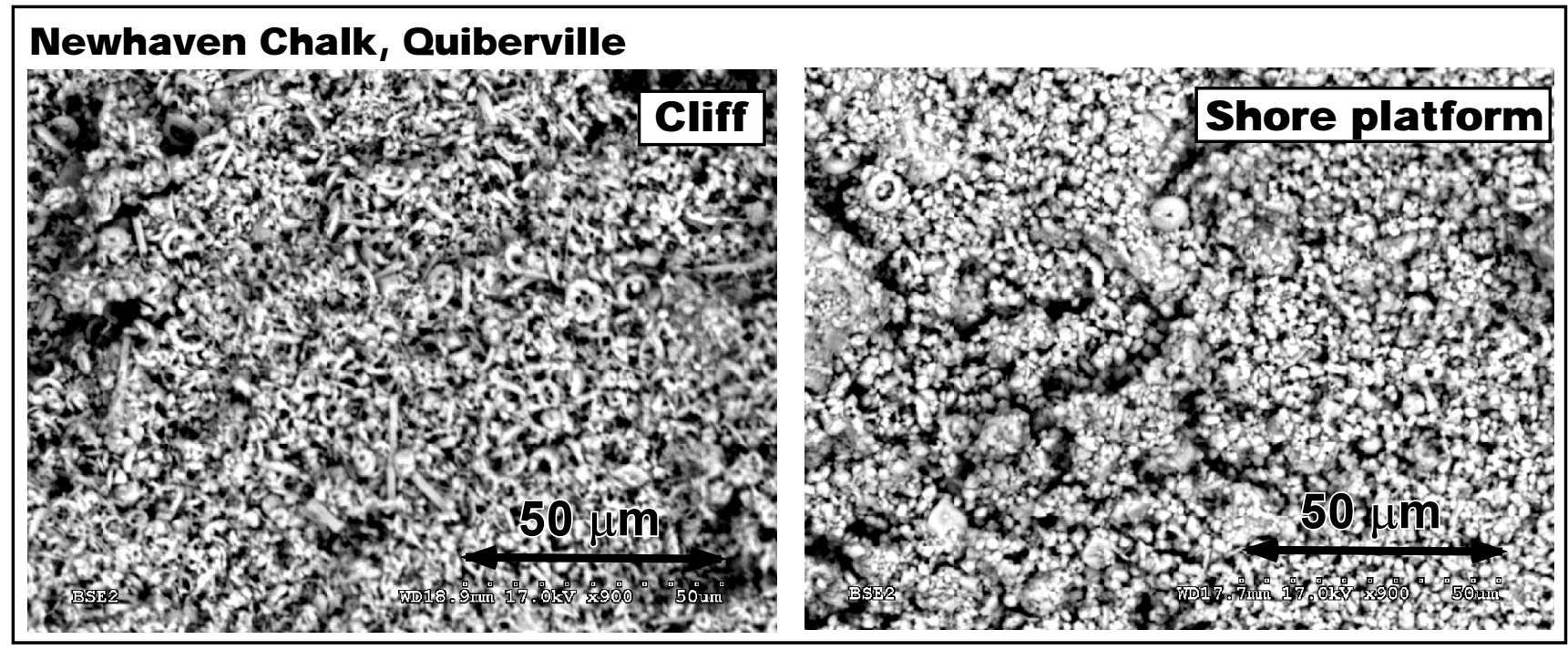




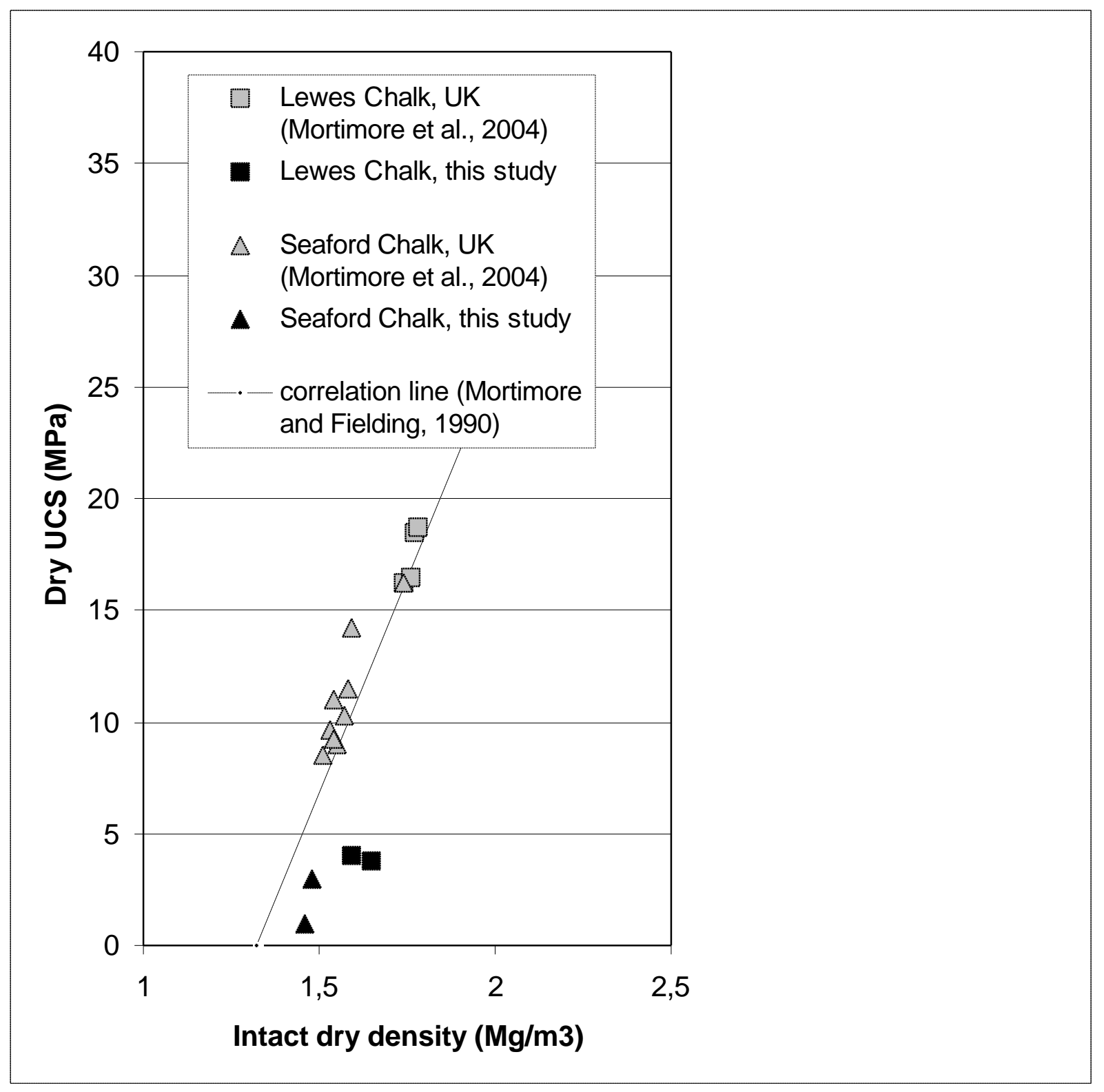


Lewes Chalk-

borehole - Bois de Cise
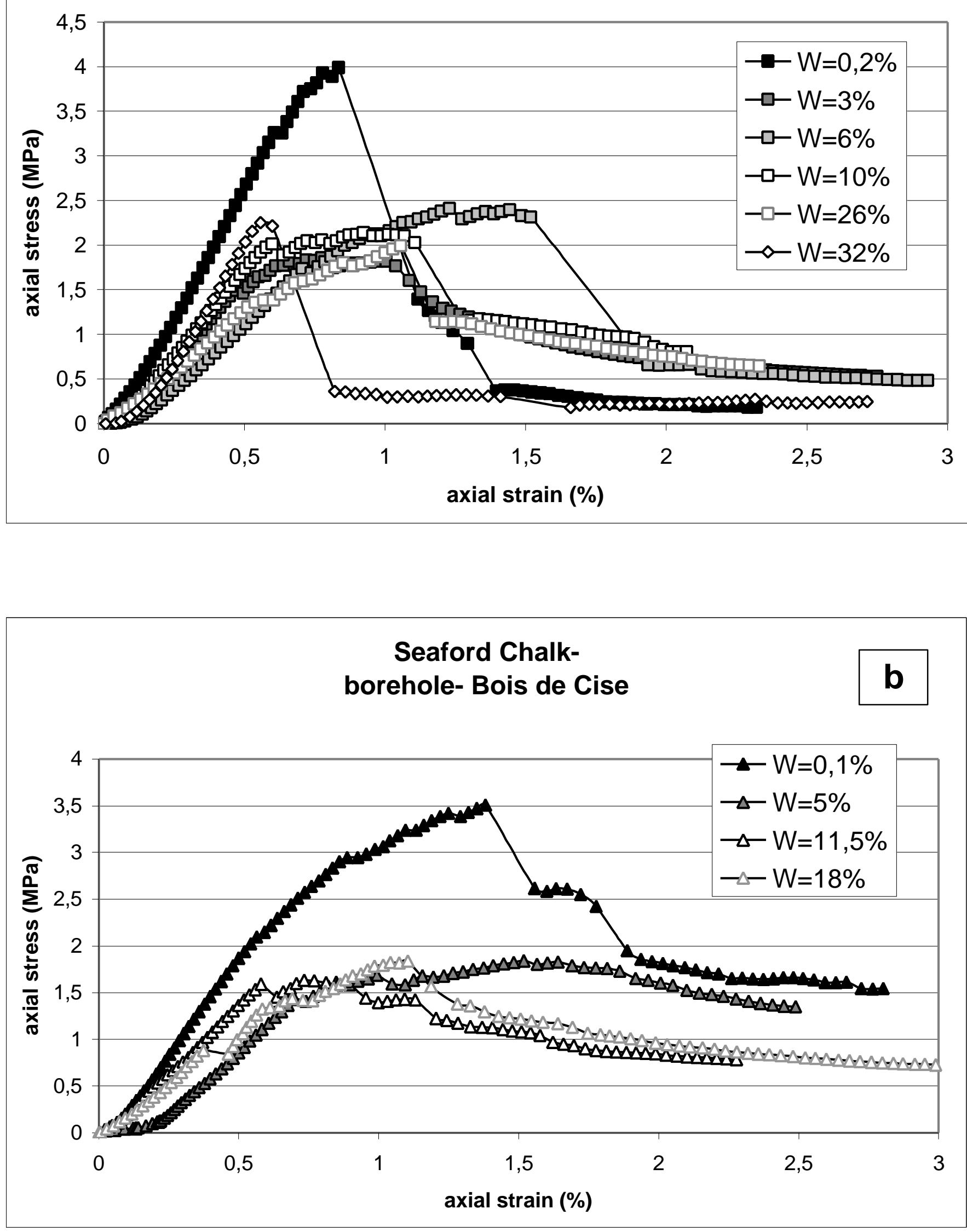

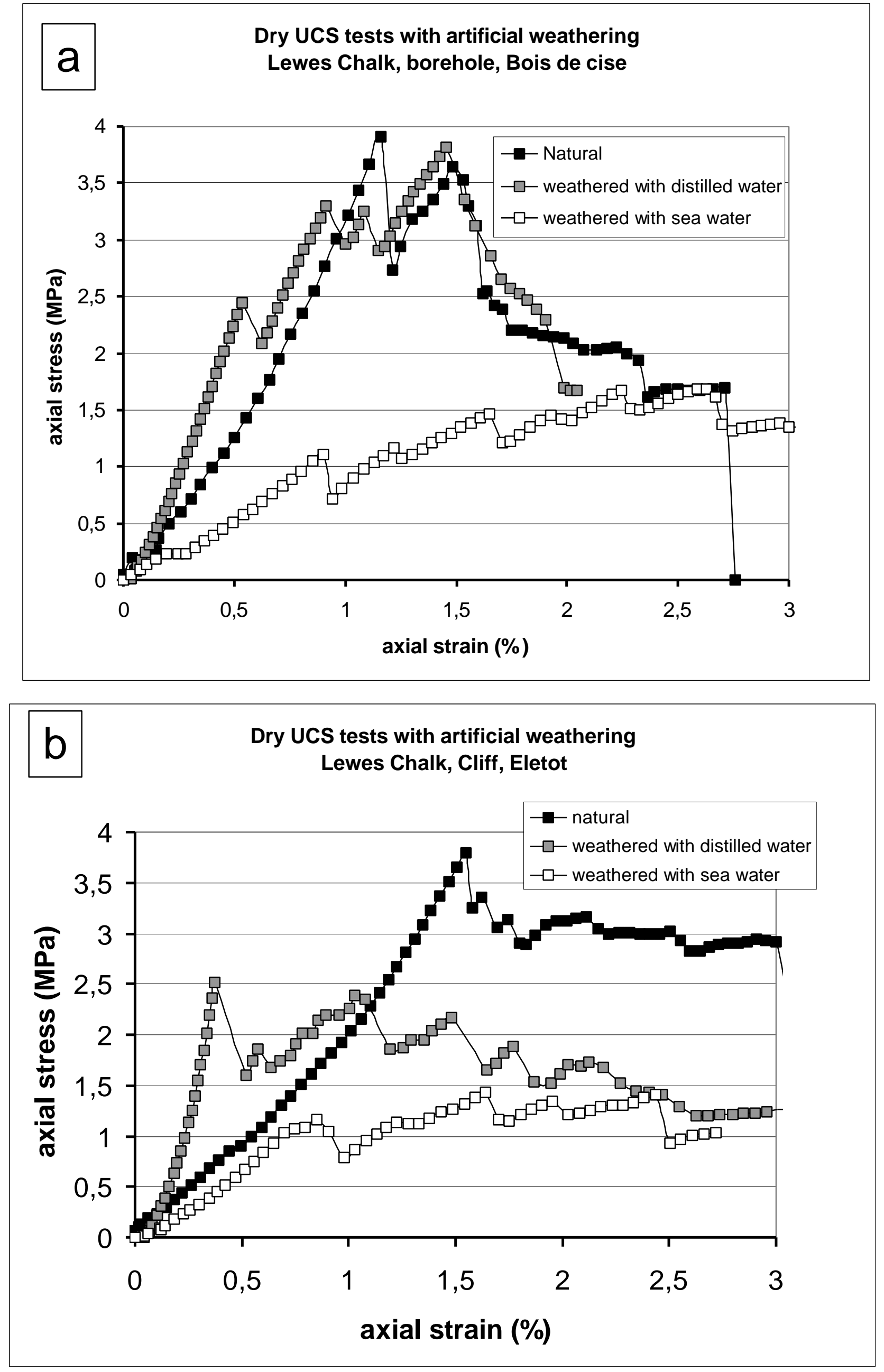

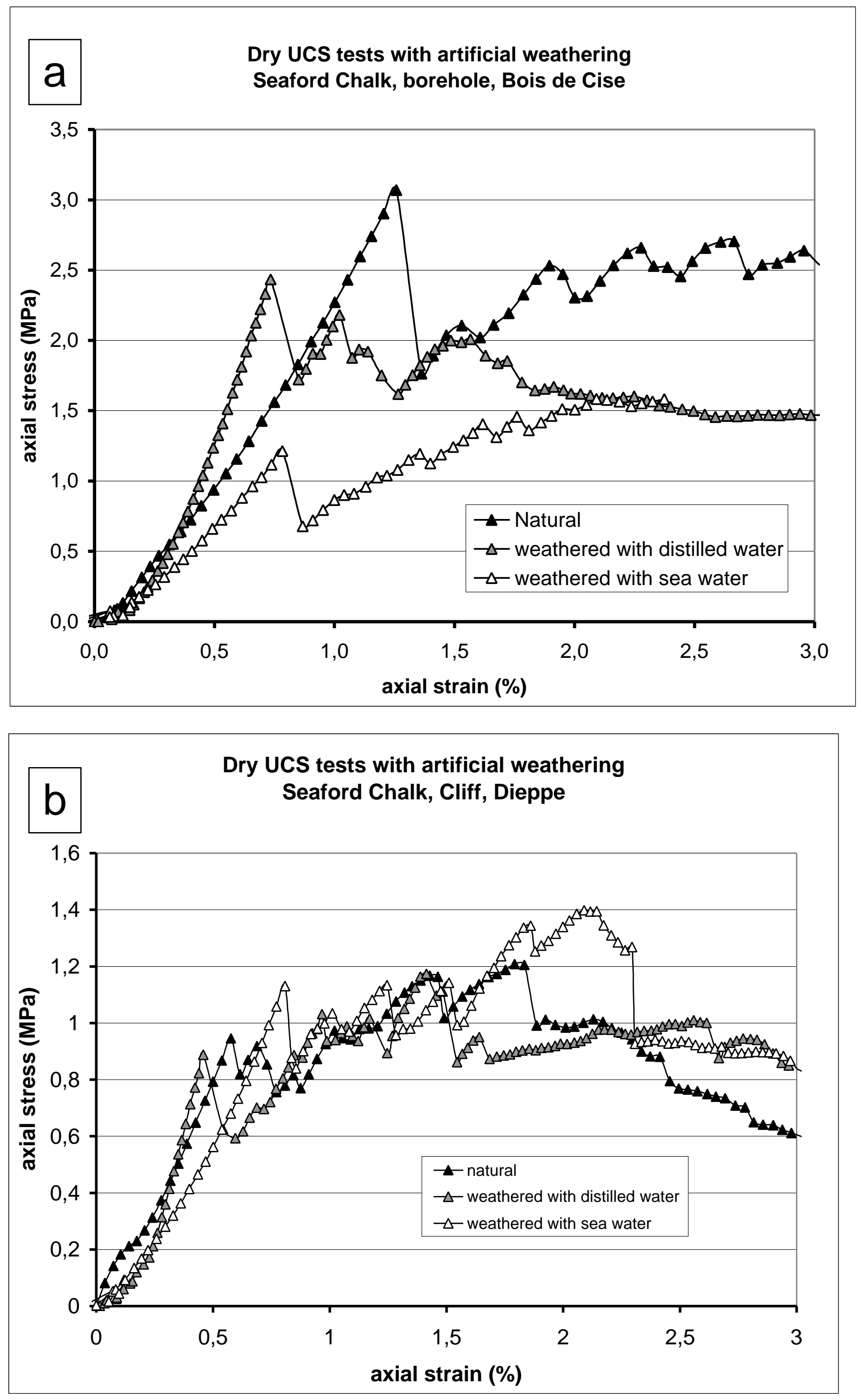

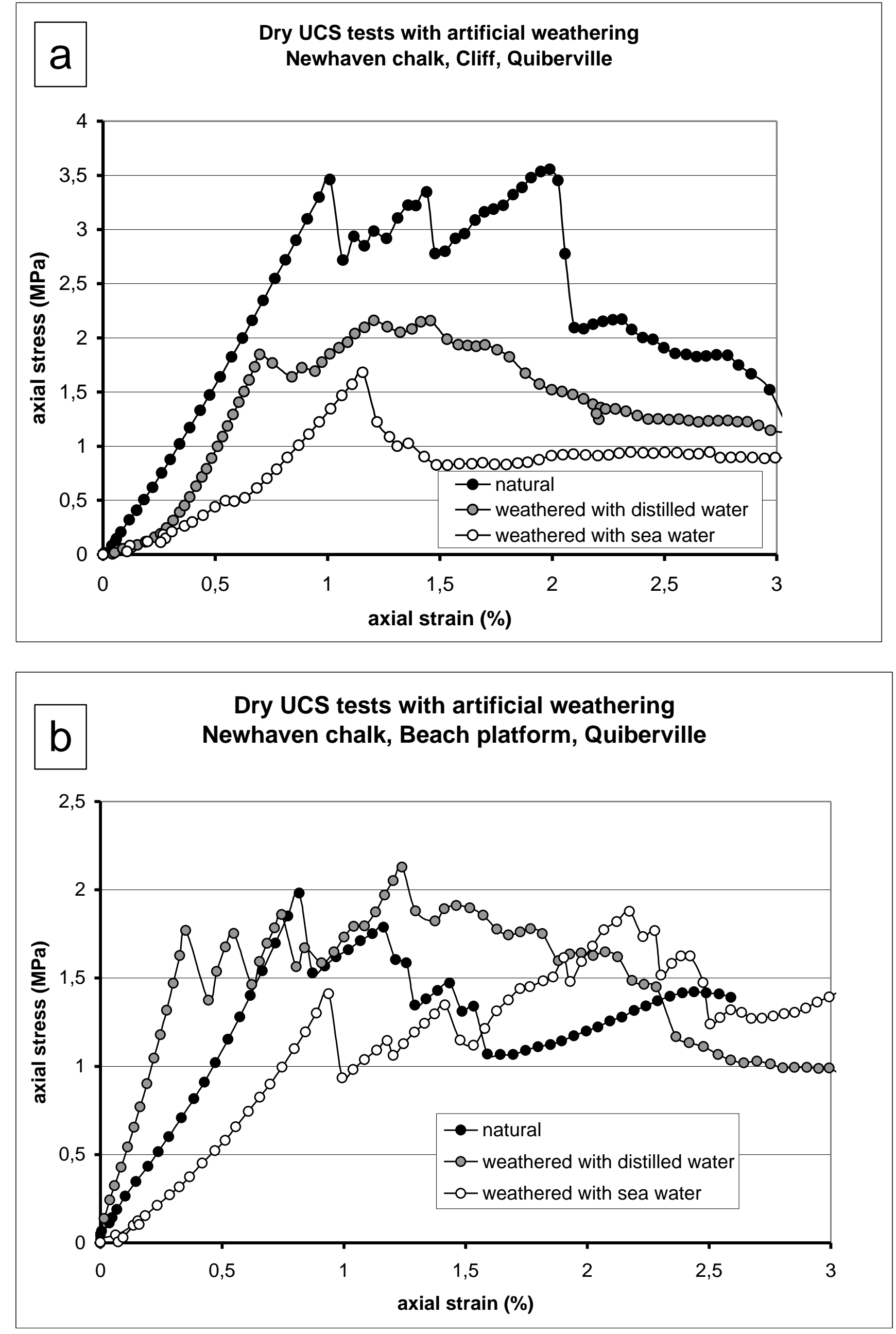

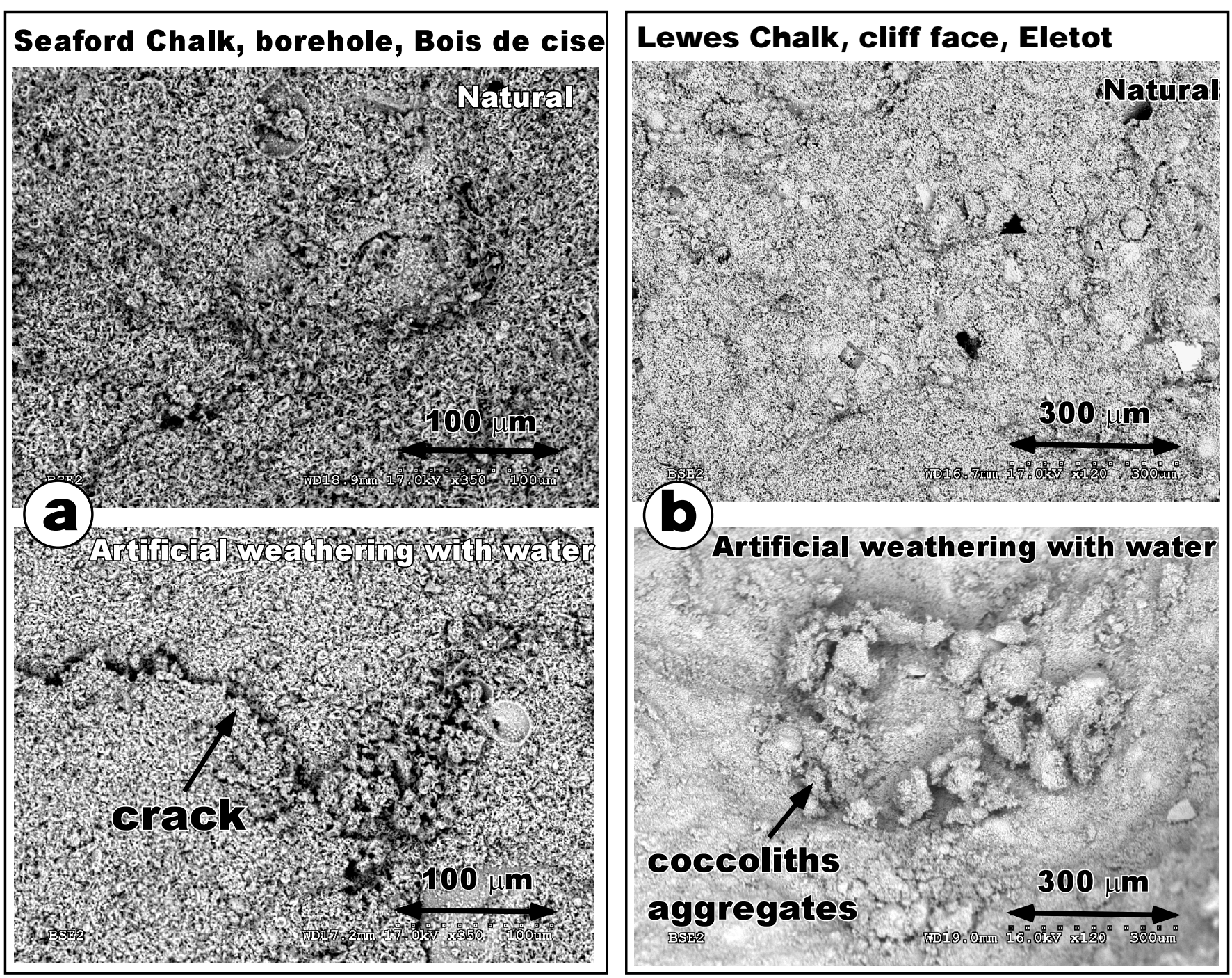


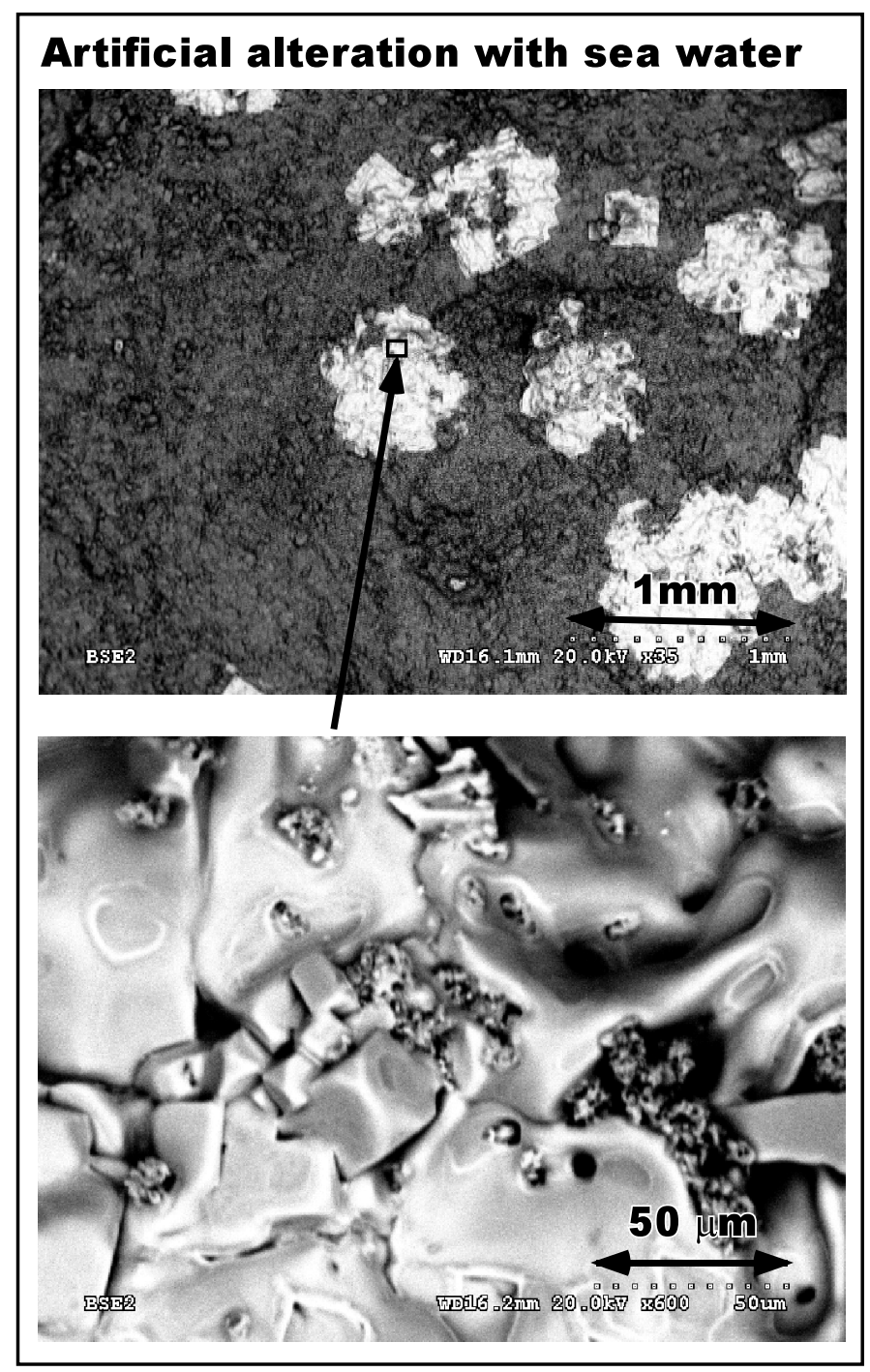




\begin{tabular}{|c|c|c|c|c|c|c|c|c|c|c|}
\hline Chalk sample & $\begin{array}{c}\text { Chalk } \\
\text { cylinders }\end{array}$ & $\begin{array}{c}\text { Natural } \\
\text { moisture } \\
\text { content } \\
(\mathrm{Wn} \%)\end{array}$ & $\begin{array}{c}\text { Degree of } \\
\text { saturation } \\
{ }^{*}(\mathrm{Sr} \%)\end{array}$ & $\begin{array}{l}\text { Dry Rc } \\
\max \\
(\mathrm{MPa})\end{array}$ & $\begin{array}{c}\text { Young's } \\
\text { modulus } \\
\text { E t50 } \\
(\mathrm{GPa})\end{array}$ & $\begin{array}{l}\text { Density } \gamma \\
(\mathrm{Mg} / \mathrm{m} 3)\end{array}$ & $\begin{array}{c}\text { Dry } \\
\text { Density } \\
\gamma d^{*} \\
(\mathrm{Mg} / \mathrm{m} 3)\end{array}$ & $\begin{array}{l}\text { void } \\
\text { ratio } \\
(\mathrm{e})^{*}\end{array}$ & $\begin{array}{c}\text { Porosity } \\
(n)^{*}\end{array}$ & $\begin{array}{l}\text { Weight loss } \\
\text { after } \\
\text { weathering } \\
(\%)\end{array}$ \\
\hline $\begin{array}{c}\text { Lewes Chalk-borehole- } \\
\text { Bois de Cise }\end{array}$ & $\begin{array}{c}\text { Natural } \\
\text { Altered-DW } \\
\text { Altered-SW }\end{array}$ & 9,7 & 37 & $\begin{array}{c}4 \\
2,44 \\
1,16\end{array}$ & $\begin{array}{c}0.42 \\
0.5 \\
0.13\end{array}$ & 1,74 & 1,59 & 0,7 & 0,41 & $\begin{array}{c}10,69 \\
5,73\end{array}$ \\
\hline $\begin{array}{c}\text { Seaford Chalk-borehole- } \\
\text { Bois de Cise }\end{array}$ & $\begin{array}{c}\text { Natural } \\
\text { Altered-DW } \\
\text { Altered-SW }\end{array}$ & 18,9 & 60 & $\begin{array}{c}3 \\
2,43 \\
1,21 \\
\end{array}$ & $\begin{array}{c}0.26 \\
0.52 \\
0.2 \\
\end{array}$ & 1,76 & 1,48 & 0,85 & 0,46 & $\begin{array}{c}8,89 \\
9,6 \\
\end{array}$ \\
\hline Lewes Chalk-Cliff-Eletot & $\begin{array}{c}\text { Natural } \\
\text { Altered-DW } \\
\text { Altered-SW }\end{array}$ & 9,6 & 40 & $\begin{array}{l}3,8 \\
2,51 \\
1,02\end{array}$ & $\begin{array}{l}0.18 \\
0.83 \\
0.18\end{array}$ & 1,8 & 1,65 & 0,64 & 0,33 & $\begin{array}{c}9,33 \\
7,2\end{array}$ \\
\hline $\begin{array}{l}\text { Seaford Chalk-cliff- } \\
\text { Dieppe }\end{array}$ & $\begin{array}{c}\text { Natural } \\
\text { Altered-DW } \\
\text { Altered-SW }\end{array}$ & 22,1 & 70 & $\begin{array}{l}0,94 \\
0,88 \\
1,13\end{array}$ & $\begin{array}{c}0.2 \\
0.32 \\
0.16\end{array}$ & 1,78 & 1,46 & 0,85 & 0,34 & $\begin{array}{c}3,6 \\
4,83\end{array}$ \\
\hline $\begin{array}{c}\text { Newhaven Chalk-Cliff- } \\
\text { Quiberville }\end{array}$ & $\begin{array}{c}\text { Natural } \\
\text { Altered-DW } \\
\text { Altered-SW }\end{array}$ & 16,8 & 55 & $\begin{array}{l}3,46 \\
1,84 \\
1,68 \\
\end{array}$ & $\begin{array}{l}0.36 \\
0.41 \\
0.23 \\
\end{array}$ & 1,73 & 1,48 & 0,82 & 0,36 & $\begin{array}{l}10,32 \\
11,08\end{array}$ \\
\hline $\begin{array}{l}\text { Newhaven chalk-Beach } \\
\text { platform-Quiberville }\end{array}$ & $\begin{array}{c}\text { Natural } \\
\text { Altered-DW } \\
\text { Altered-SW }\end{array}$ & 17 & 63 & $\begin{array}{l}1,98 \\
1,77 \\
1,41\end{array}$ & $\begin{array}{l}0.24 \\
0.45 \\
0.17\end{array}$ & 1,82 & 1,56 & 0,73 & 0,32 & $\begin{array}{c}7,55 \\
9,2\end{array}$ \\
\hline
\end{tabular}




\begin{tabular}{|c|c|c|c|c|c|c|c|c|c|c|c|}
\hline Chalk sample & $\begin{array}{c}\text { Chalk } \\
\text { cylinders }\end{array}$ & $\begin{array}{c}\text { Natural } \\
\text { moisture } \\
\text { content } \\
(\mathrm{Wn} \%)\end{array}$ & $\begin{array}{l}\text { Imposed } \\
\text { moisture } \\
\text { content } \\
(\mathrm{W} \%)\end{array}$ & $\begin{array}{c}\text { Degree of } \\
\text { saturation } \\
{ }^{*}(\mathrm{Sr} \%)\end{array}$ & $\begin{array}{l}\text { Rc max } \\
(\mathrm{MPa})\end{array}$ & $\begin{array}{c}\text { Young's } \\
\text { modulus } \\
\text { (MPa) }\end{array}$ & $\begin{array}{l}\text { Density } \gamma \\
(\mathrm{Mg} / \mathrm{m} 3)\end{array}$ & $\begin{array}{c}\text { Dry } \\
\text { Density } \\
\gamma d^{\star} \\
(\mathrm{Mg} / \mathrm{m} 3)\end{array}$ & $\begin{array}{l}\text { void } \\
\text { ratio } \\
(e)^{\star}\end{array}$ & $\begin{array}{l}\text { Porosity } \\
(n)^{\star}\end{array}$ & $\begin{array}{c}\text { permeability } \\
(\mathrm{m} / \mathrm{s})\end{array}$ \\
\hline $\begin{array}{c}\text { Lewes Chalk-borehole- } \\
\text { Bois de Cise }\end{array}$ & $\begin{array}{l}\text { Natural } \\
\text { LBDC-1 } \\
\text { LBDC-2 } \\
\text { LBDC-3 } \\
\text { LBDC-4 }\end{array}$ & 27 & $\begin{array}{c}0,1 \\
5 \\
11,5 \\
18\end{array}$ & $\begin{array}{c}89 \\
0,3 \\
16,8 \\
38,8 \\
60,7\end{array}$ & $\begin{array}{c}3,5 \\
1,6 \\
1,6 \\
0,84\end{array}$ & $\begin{array}{c}1,33 \\
1,9 \\
1,2 \\
1,49\end{array}$ & 1,88 & 1,48 & 0,8 & 0,45 & 2 10-7 \\
\hline $\begin{array}{c}\text { Seaford Chalk-borehole } \\
\text { Bois de Cise }\end{array}$ & $\begin{array}{l}\text { Natural } \\
\text { SBDC-1 } \\
\text { SBDC-2 } \\
\text { SBDC-3 } \\
\text { SBDC-4 } \\
\text { SBDC-5 } \\
\text { SBDC-6 }\end{array}$ & 27 & $\begin{array}{c}0,2 \\
3,1 \\
5,7 \\
10 \\
26 \\
31,7\end{array}$ & $\begin{array}{c}85,7 \\
0,6 \\
9,8 \\
18,1 \\
31,7 \\
82,5 \\
100\end{array}$ & $\begin{array}{l}3,98 \\
1,46 \\
2,41 \\
2,01 \\
1,99 \\
2,25\end{array}$ & $\begin{array}{l}3,32 \\
2,78 \\
1,06 \\
3,55 \\
1,52 \\
5,24\end{array}$ & 1,85 & 1,45 & 0,85 & 0,46 & 3,5 10-7 \\
\hline
\end{tabular}

